\title{
DESIGN OF AN EXPERIMENTAL INCINERATOR FOR ALPHA WASTE
}

J. H. WARREN

\section{AUGUST 1979}

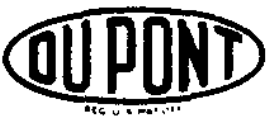

SAVANNAH RIVER LABORATORY AIKEN, SOUTH CAROLINA 29801 
This report was prepored as an account of work sponeored by the United Stutes Government. Nolther the United Stetes nor the United Stetes Department of Energy, nor any of their employees, make any warranty. ex. proses or implled, or assumes any legal lisbility of rasponslbitity for the eccuracy, completenese, or usefuinese of any informetlon, apperatus, product, or process disclosed, or represents that its use would not intringe privately owned rights. Reterence harein to any epecific commercial pro-

duct, procese, or earvice by trade name, merk, manufecturer, or otherwies, does not necessarily constitute or imply its endorsement, recommendetion. or fovoring by the United Stetes Government or eny agency thereof. The viows and opinions of euthors expresesd herain do not necesearily state or reflect thow of the United States Government or eny eaency thereof.

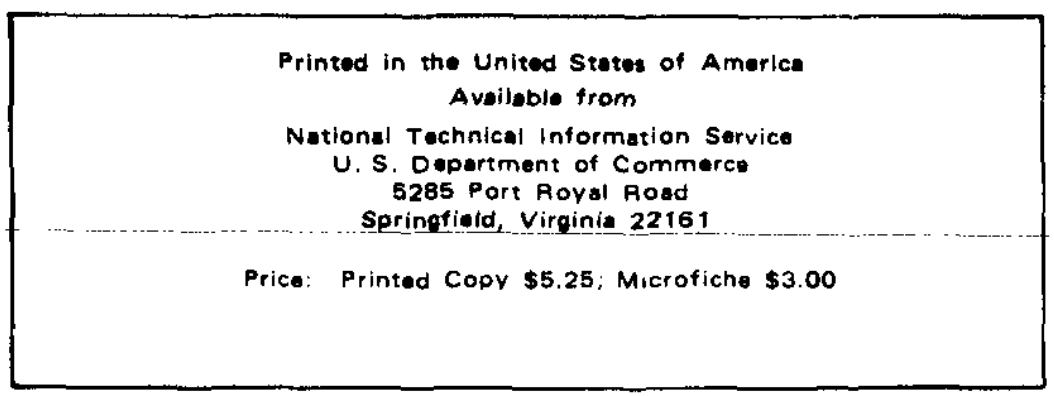




\section{DESIGN OF AN EXPERIMENTAL INCINERATOR FOR ALPHA WASTE}

by

J. H. Warren

Approved by

G. F. Merz, Research Manager

Reactor Engineering Division

Publication Date: August 1979

ISSUED BY E. I. DU PONT DE NEMOURS AND COMPANY SAVANNAH RIVER LABORATORY AIKEN, SOUTH CAROLINA 2980?

PREPARED FOR THE U. S. DEPARTMENT OF ENERGY UNDER CONTRACT AT(07.2)-1 
An electrically heated controlled-air two-stage incinerator has been designed at the Savannah River Laboratory for burning small volumes $(5 \mathrm{~kg} / \mathrm{hr})$ of solid wastes. Distinguishing features of the design are compactness, relatively lightweight, and ease of assembly made possible by using prefabricated ceramic components to form two combustion chambers surrounded by packed fiber insulation within a steel case. Electric girdle heaters around the two combustion chambers provide 600 to $1000^{\circ} \mathrm{C}$. These temperatures combined with controlled air give minimum ash entrainment and long combustion gas residence times to yield $210^{9}$ off-gas decontamination factors with conventional off-gas cleaning equipment. After decommissioning, the design allows for ease of disassembly and convenient disposal of the ceramic components. 


\section{CONTENTS}

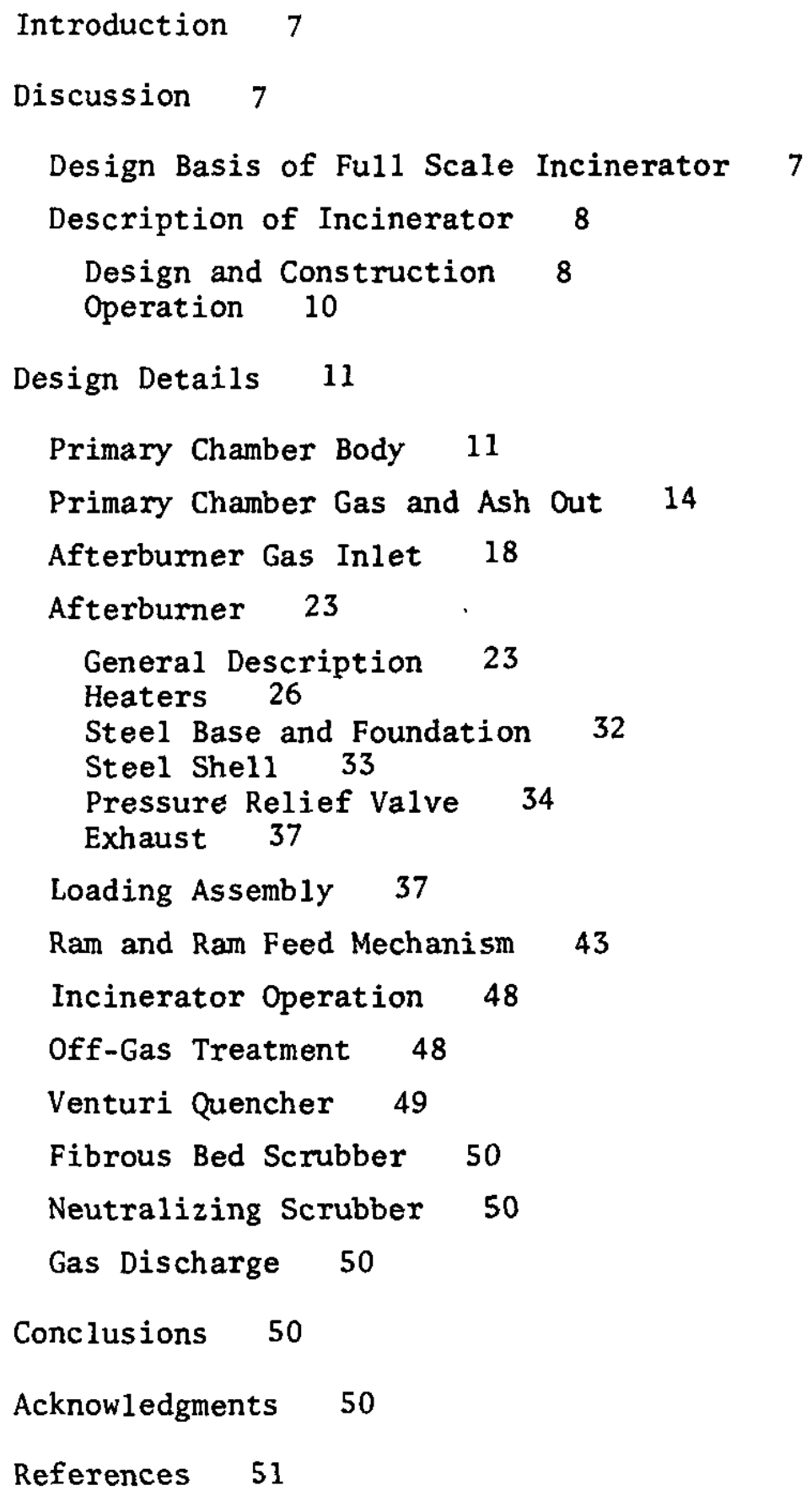




\section{LIST OF FIGURES}

Drawing No.

1 Full Scale Alpha Waste Incinerator for Tests with Nonradioactive Wastes 9

2 Elevation Sections $12 \quad$ ST-MDX5-9288

3 P1an Sections $13 \quad$ ST-MDX5-9286

4 Primary Chamber Connection Parts $15 \quad$ ST-MDX5-9289

5 Ash Out Subassembly $16 \quad$ ST-MDX5-9303

$\begin{array}{llll}6 & \text { Base Assemb1y } 17 & \text { ST-MDX5-9328 }\end{array}$

$\begin{array}{llll}7 & \text { Air Mixer } 19 & \text { ST-MDX5-9329 }\end{array}$

8 Afterburner Parts $20 \quad$ ST-MDX5-9275

9 Heaters $21 \quad$ ST-MDX5-9282

10 Flow Sheet for Incinerator Components ST5-19818 Test Facility 22

11 Cast Manifold Subassemb1y $24 \quad$ ST-MDX5-9290

12 Cast Manifold Unit Details $25 \quad$ ST-MDX5-9269

13 Alternate Exhaust $27 \quad$ ST-MDX5-9339

14 Heater Wiring Diagram $30 \quad$ ST-MDX5-9332

15 Sight Port and Heater Straps $31 \quad$ ST-MDX5-9294

16 Port for Relief Valve and $\mathrm{O}_{2}$ Analyzer 35 ST-MDX5-9307

17 Exhaust Transition $38 \quad$ ST-MDX5-9312

18 Loading Assembly $39 \quad$ ST-MDX5-9300

19 Rotary Feed Magazine $40 \quad$ ST-MDX5-9355

20 Loading Mechanism Components $42 \quad$ ST-MDX5-9314 
LIST OF FIGURES (Contd)

Drawing No.

21 Ram Details 44

ST-MDX5-9356

22 Ram Drive Assembly 46

ST-MDX5-9357

23 Ram Drive Details 47

ST-MDX5-9284

24 Incinerator Flow Diagram 49

\section{LIST OF TABLES}

1 Afterburner Volume and Residence Time as

a Function of Exhaust Tube Position 29 


\section{DESIGN OF AN EXPERIMENTAL INCINERATOR FOR ALPHA WASTE}

\section{INTRODUCTION}

A two-stage electrically heated incinerator with an off-gas system for removal of chlorides and particulates has been selected for incineration of solid Savannah River Plant (SRP) wastes contaminated with alpha-emitting transuranium (TRU) nuclides. A full-scale $(5 \mathrm{~kg} / \mathrm{hr})$ test incinerator has been designed to measure fluid dynamics, thermal cycling behavior, soot and dust entrainment, off-gas cleanup, and corrosion rates of construction materials. This incinerator will burn only uncontaminated wastes.

This experimental equipment is providing a data base for the design of a production incinerator and safety and operational procedure for routine operation. Subsequent use of this facility after the experimental phase will involve component testing and personnel training.

This report documents the design basis for the test incinerator.

\section{DISCUSSION}

\section{Design Basis of Full Scale Incinerator}

The design basis for a plant incinerator is safe operation in a radioactive environment based on demonstrated technology. A controlled-air two-stage incineration process was chosen after a survey of current literature, ${ }^{1,2}$ and visits to other DOE sites and foreign nuclear facilities. In this method of incineration, solid wastes are pyrolyzed in an air-starved primary combustion chamber; and the evolved gases are burned in excess air in an afterburner or secondary combustion chamber. The advantage of this method in TRU solid waste application is that a minimum amount of ash and solids is entrained in the off-gas, and a maximum amount of the radioactivity is retained in the ash residue.

A laboratory-scale incinerator was built in 1977, to confirm the technology developed at Windscale BNFL for burning small quantities of solid wastes. This incinerator was one-tenth $(0.5 \mathrm{~kg} / \mathrm{hr})$ the size required for production operations and was used to obtain design data and experience for design of the full-size incinerator 
described in this paper. Nonradioactive waste components, such as paper, rubber, and various plastics were burned individually to determine operating ranges for feed batch size and frequency, temperature, and air flow. Performance was measured in terms of ash and off-gas quality. Chloride corrosion effects on candidate construction materials for the full-size incinerator were also determined.

Two basic construction techniques have been used to build previous ceramic waste incinerators: refractory brick structures and prefabricated refractory-lined steel pipe structures. Both techniques result in massive and heavy structures. To maintain a compressive stress on the brick structure, the refractory brick is often backfilled with castable refractory. The castable refractory ensures the elimination of voids between the brick and the steel support housing. The second technique requires large-diameter pipe to contain the firebrick and insulation linings. A labyrinthtype afterburner is desired for increasing mixing, turbulence, and residence time of the air and gas in the afterburner. Conventional pipe elbows are smooth curves; therefore, the manufacture of a labyrinth with these standard pipe elbows does not increase the gas turbulence or residence time in the afterburner. Skilled kiln masons are required to construct and assemble both of these incinerator structures. Both designs are difficult to heat because of their large heat capacity; heater placement and repair is also difficult and expensive.

The design described in this report was developed to avoid these difficulties. The incinerator was designed with ease of fabrication and maintenance in mind. Flexibility to vary the operating conditions was also included in the design as much as possible. Some conservatisms and accessories were also included to allow for experimental variation of the original design requirements after operational experience is obtained.

Description of Incinerator

\section{Design and Construction}

The full-scale incinerator is constructed primarily of ceramic tubes surrounded by loosely packed insulation within a steel case (Figure 1). Common cast refractory tubes are connected in series by cast refractory manifolds to create a continuous tortuous path within a small volume. A11 of the refractory components are manufactured at a vendor shop and then assembled onplant without the requirement of skilled kiln masons. The vertical afterburner tubes and end manifolds maintain an airtight seal by the compressive load of their own weight. Thermal expansion effects are compensated for by the free-standing tubes and the independent end manifolds. 


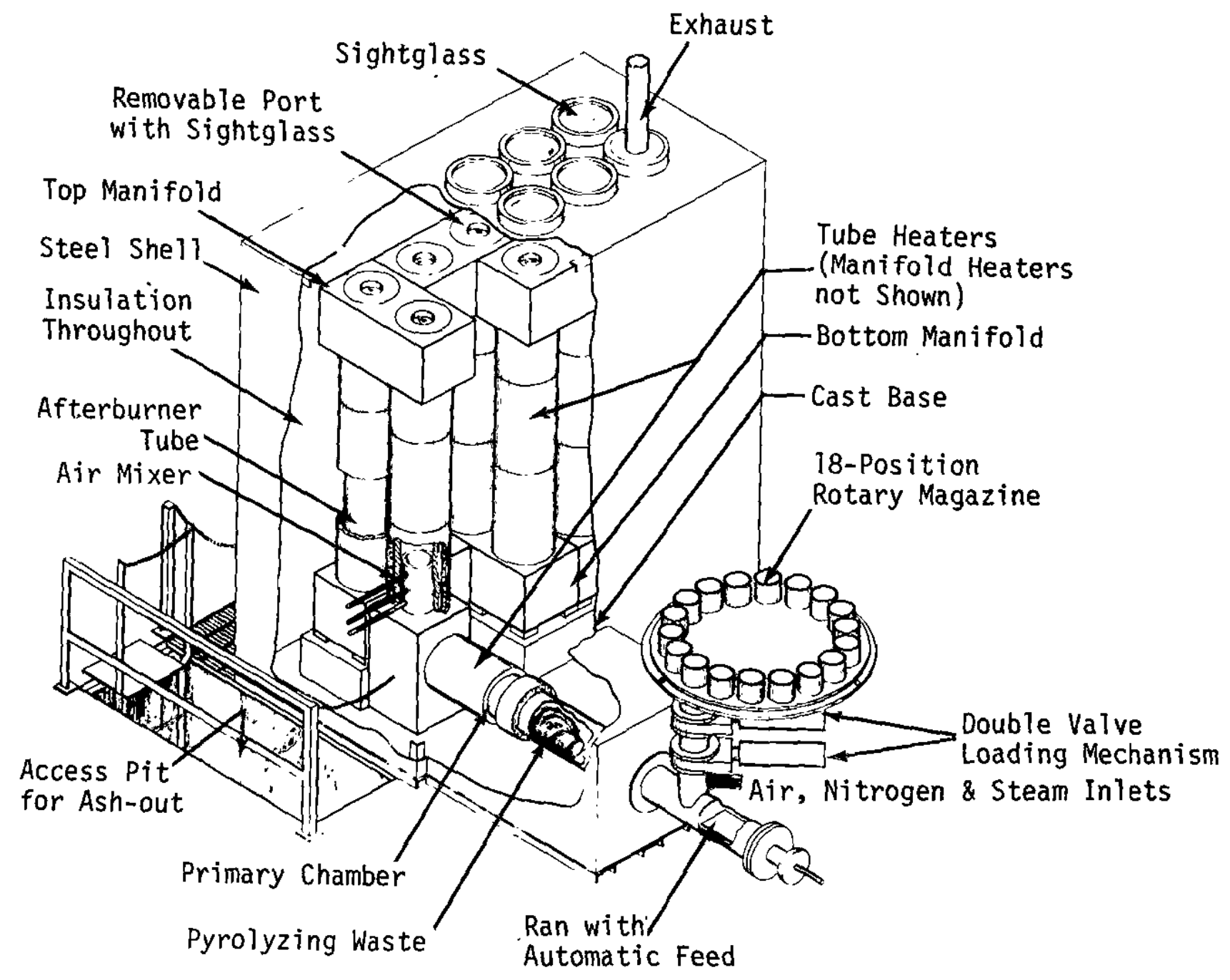

FIGURE 1. Ful1-Scale Alpha Waste Incinerator for Tests with Nonradioactive Wastes 
The small amount of alpha waste burned in the incinerator has a low thermal yield; therefore, supplemental heating is required. Electric heating is used for intrinsic safety with highly contaminated transuranic wastes which will burn in future plant incinerators. Gas heating increases the hazard of explosion or fire. Process heat is provided by girdle heaters on the outside of the tubes and flat plate heaters on the end manifolds. Power to the primary is $4.8 \mathrm{~kW}$ divided into three zones; power to the afterburner is $5 \mathrm{~kW}$ per tube and 11.4 watts/in. ${ }^{2}$ on the flat plate heaters. Total heat input to the incinerator is $125 \mathrm{~kW}$. Replacement of individual tubes, end manifolds, and heaters is made through access plates in the steel casing. The entire unit is insulated with a minimum of 10 in. of fiber blanket insulation and enclosed in a $1 / 4$-in.-thick air-tight steel shell about $9 \mathrm{ft}$ long, $5 \mathrm{ft}$ wide, and $10 \mathrm{ft}$ high. The incinerator primary casing projects from the front of the afterburner and is $7 \mathrm{ft}$ long, $3 \mathrm{ft}$ wide, and $3 \mathrm{ft}$ high.

\section{Operation}

Solid waste feed is shredded, weighed in $300-\mathrm{g}$ quantities, and packaged in 4-in. by 9-in. long cylindrical paper packages. Waste packages are dropped from a rotating feed magazine and rammed into a silicon carbide horizontal primary combustion chamber which has an inside diameter of 8-1/2 in. and an outside diameter of 11 in. The waste is pyrolyzed in the primary combustion chamber at 600 to $800^{\circ} \mathrm{C}$ with substoichiometric air purge. Steam or nitrogen addition may also be used to control pyrolysis rates.

At the exit of the primary tube, gases and solid ash residue are separated by gravity. Ashes fall by gravity into the ash collection chamber where the ash is cooled and stored for removal. Ash is removed through two 8 -in. isolation valves in series.

Pyrolysis gases from the burning waste are burned in a mixing nozzle where excess air is added in the first refractory tube of the vertical afterbumer. As shown in Figure 1, the afterburner consists of nine $90 \%$ alumina tubes which are 64 in. long and have an inside diameter of $8-1 / 2$ in. and an outside diameter of $11 \mathrm{in}$. These tubes are connected in series by the end manifold blocks. The purpose of the long labyrinth afterburner is to provide an of $f$-gas residence time of $\imath 3$ seconds for a flow rate of $\sim 200$ ACFM at $1000^{\circ} \mathrm{C}$. This residence time is required to burn off any carbon particulates and, combined with the flow reversals of the tortuous path, contributes to a particulate-free exhaust gas. The cast manifold end blocks are provided with access plugs for cleanout, instrument probes and sight glasses for direct observation or 
inspection. An exhaust tube can be inserted into the manifold to test the effect of varying afterburner volumes (hence, gas residence time) on exhaust gas particulates.

Incinerator draft is maintained with an external blower placed after conventional off-gas quench and neutralizing scrubber equipment and HEPA filtering. The incinerator is always operated with subatmospheric pressure to ensure inleakage, thus minimizing the escape of combustion products.

Figures 2 and 3 show detailed sections of the incinerator assembly illustrated isometrically in Figure 1. The rest of this report will discuss the design features of the incinerator components. The primary chamber and afterburner will be discussed first, with the associated mechanisms and operation discussed last.

\section{DESIGN DETAILS}

\section{Primary Chamber Body}

The primary chamber is attached to the primary inlet chamber as a solid connection shown in Figure 2. The seal is made with Fiberfrax ${ }^{*}$ rope dipped in alumina silicate cement and packed around the tube.

The chamber is made of Refrax* 20, a silicon-nitride-bonded silicon carbide. Silicon carbide was chosen because its tenfold higher thermal conductivity over alumina facilitates heatup. The chamber is $66 \mathrm{in.}$ long, with an inner diameter of $8.5 \mathrm{in.}$ and an outer diameter of 11.0 in. The entire primary chamber is surrounded by 10 in. of Fiberfrax insulation and a 1/4-in.-thick steel shel1. The chamber is heated with easily replaceable girdle heaters which provide a total of $4.8 \mathrm{~kW}$. The heaters are divided into three separately controllable groups to maintain an axial temperature gradient in the primary chamber. Because of the gradient, the package is not pyrolyzed before it leaves the loading zone of the primary chamber. The primary chamber tube and heaters are supported by saddles made from $K-30^{* *}$ insulating firebrick.

Air enters the primary chamber at the loading mechanism to provide some oxygen to reduce the carbon content of the ash through formation of $\mathrm{CO}$. However, the amount of air is in less than stoichiometric amounts to prevent combustion in the primary so as not to entrain the ash in the pyrolysis gas. Pyrolysis gas

\footnotetext{
* Trademark of The Carborundum Co.

** Trademark of The Babcock \& Wi 1 cox Co.
} 


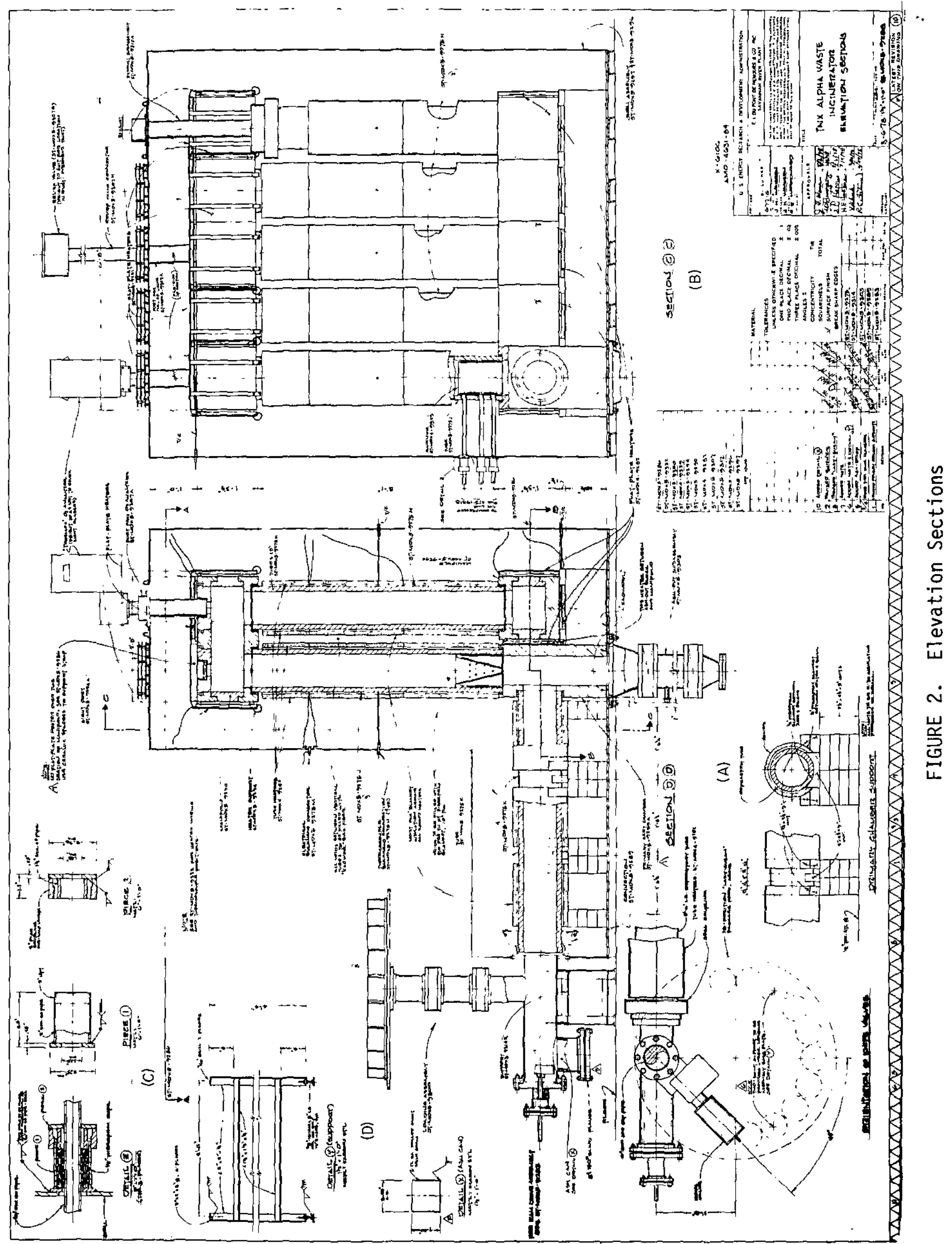



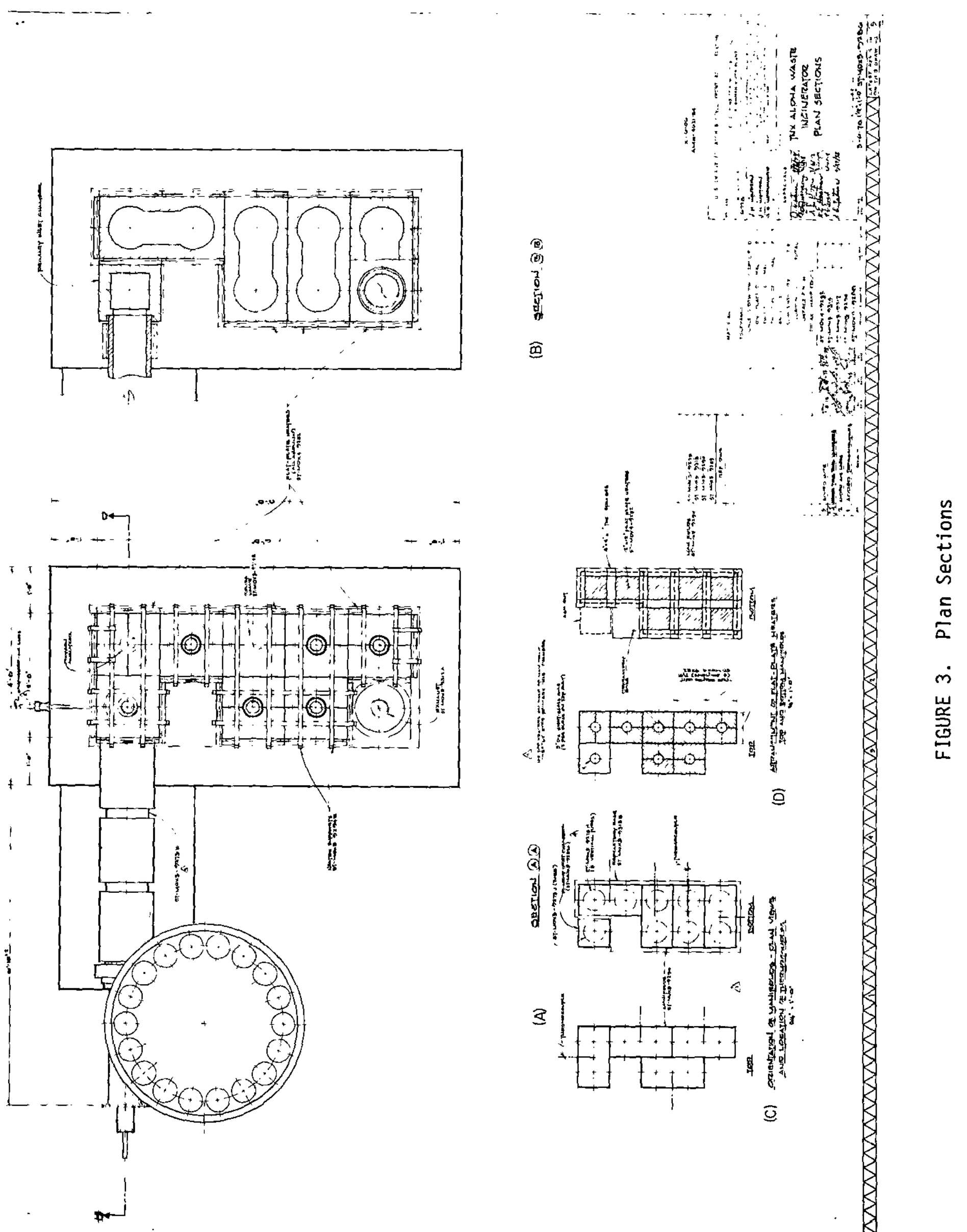
leaves the primary chamber where it rises into the afterburner through an air-mixing chamber. Up to $200 \%$ excess air can be added to initiate combustion of the gas in the air-mixing chamber.

\section{Primary Chamber Gas and Ash Out}

The gas and ash from the primary chamber tube enter the cast Cerox* $700,90 \%$ alumina disengaging section (Figure $4 \mathrm{a}$ ), shown in Figure 2. The hot gases rise upward into the afterburner and the ashes fall downward into the ash-out subassembly (Figure 5) with minimum entrainment into the afterburner. The disengaging section sits on a 1/2-in.-thick Kaowool* blanket on top of the 1/2-in.thick steel base plate (Figure 6). The ash falls directly into the ash-out subassembly through a 7-3/4 $\times 9$-in. rectangular hole in the base plate. The ash-out subassembly is located in a pit below the incinerator (Figure 1).

The ash-out subassembly consists of two 8-in. Dezurik ${ }^{*}$ knife gate valves with metal-to-metal seats two feet apart centerline of knife to centerline of knife which produces a storage volume of $0.7 \mathrm{ft}^{3}$. For the design of $5 \mathrm{~kg} / \mathrm{hr}(12 \mathrm{~b} / \mathrm{hr})$ and assuming one pound of ash is produced per $20 \mathrm{lb}$ of waste and an ash density of $16.0 \mathrm{lb} / \mathrm{ft}^{3}$, the $0.7 \mathrm{ft}^{3}$ ash storage is large enough for 18 to $19 \mathrm{hr}$ of operation. A transition piece (Figure $5 \mathrm{e}$ ) is used to reduce the large $7-3 / 4 \times 9$-in. hole in the base plate to the 8-in.-diameter pipe without having any abrupt changes where ash may hang up. Drilled blind flanges and reducers rolled from plate reducers were chosen for the transition pieces, as opposed to standard flanges and reducers in order to shorten the total assembly length and hence, the depth of the pit. The ash-out subassembly is fastened to the bottom of the base plate by studs welded to the base plate.

The interior of the knife gate valves is 316 stainless steel and should have a $2-y \mathrm{y}$ life with $600^{\circ} \mathrm{C}$ ash falling on the valves. Because of the metal valve seats required for $600^{\circ} \mathrm{C}$, a 20 -in. vacuum maintainable by the waste inlet valves cannot be guaranteed. For this reason, a 4-in.-diameter water-cooled plug valve is installed below the bottom knife valve to maintain this vacuum. It will be opened and closed with the same switch that operates the bottom knife valve. During normal operation, the plug valve and the bottom knife valve are closed with the top knife valve open. Ash then falls directly on top of the bottom knife valve where it cools. Before the two bottom valves are opened, the top valve must be closed for safety. Ash is removed

* Trademark of The Babcock \& Wilcox Co.

** Trademark of The Dezurik Co. 


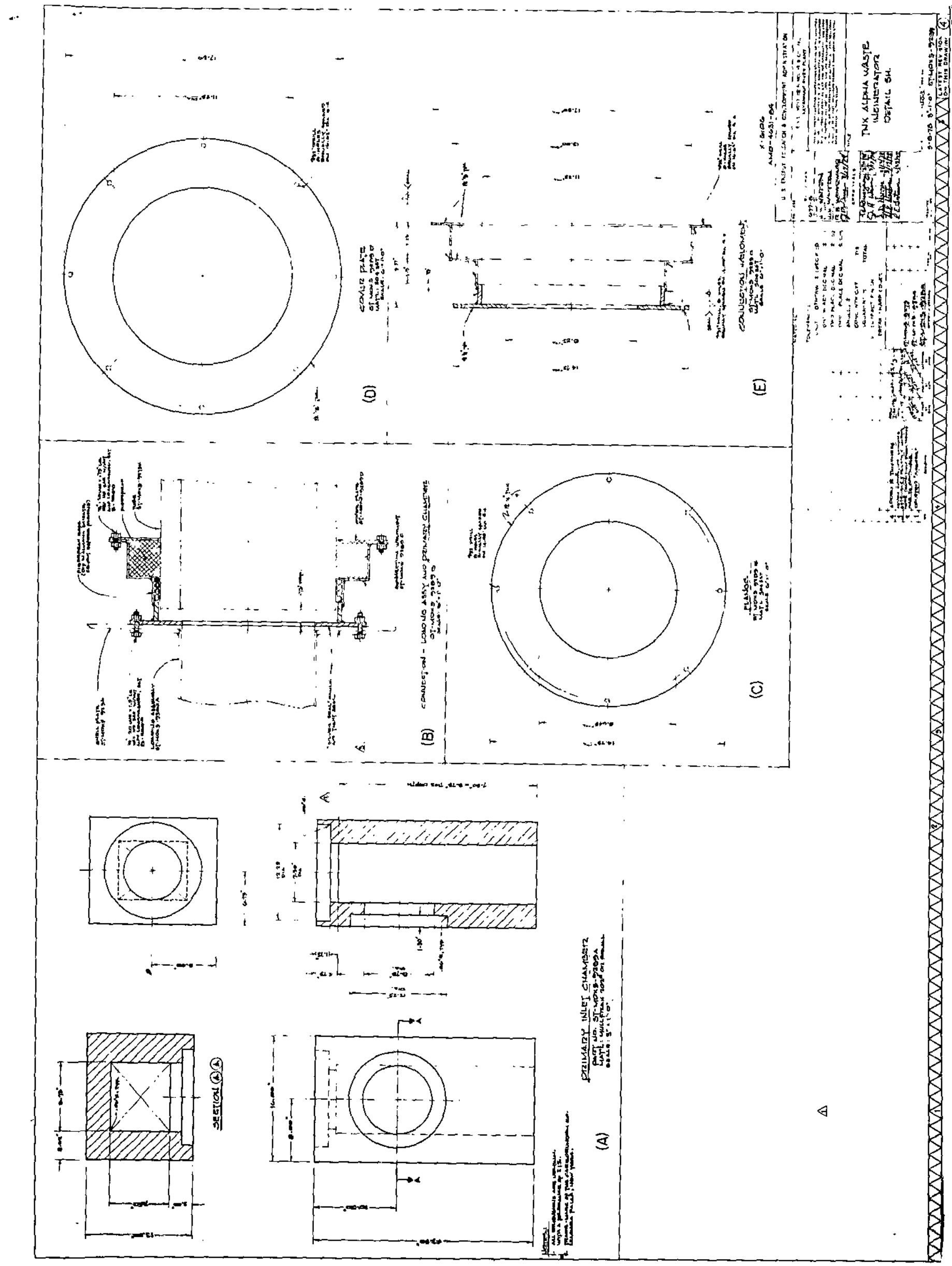




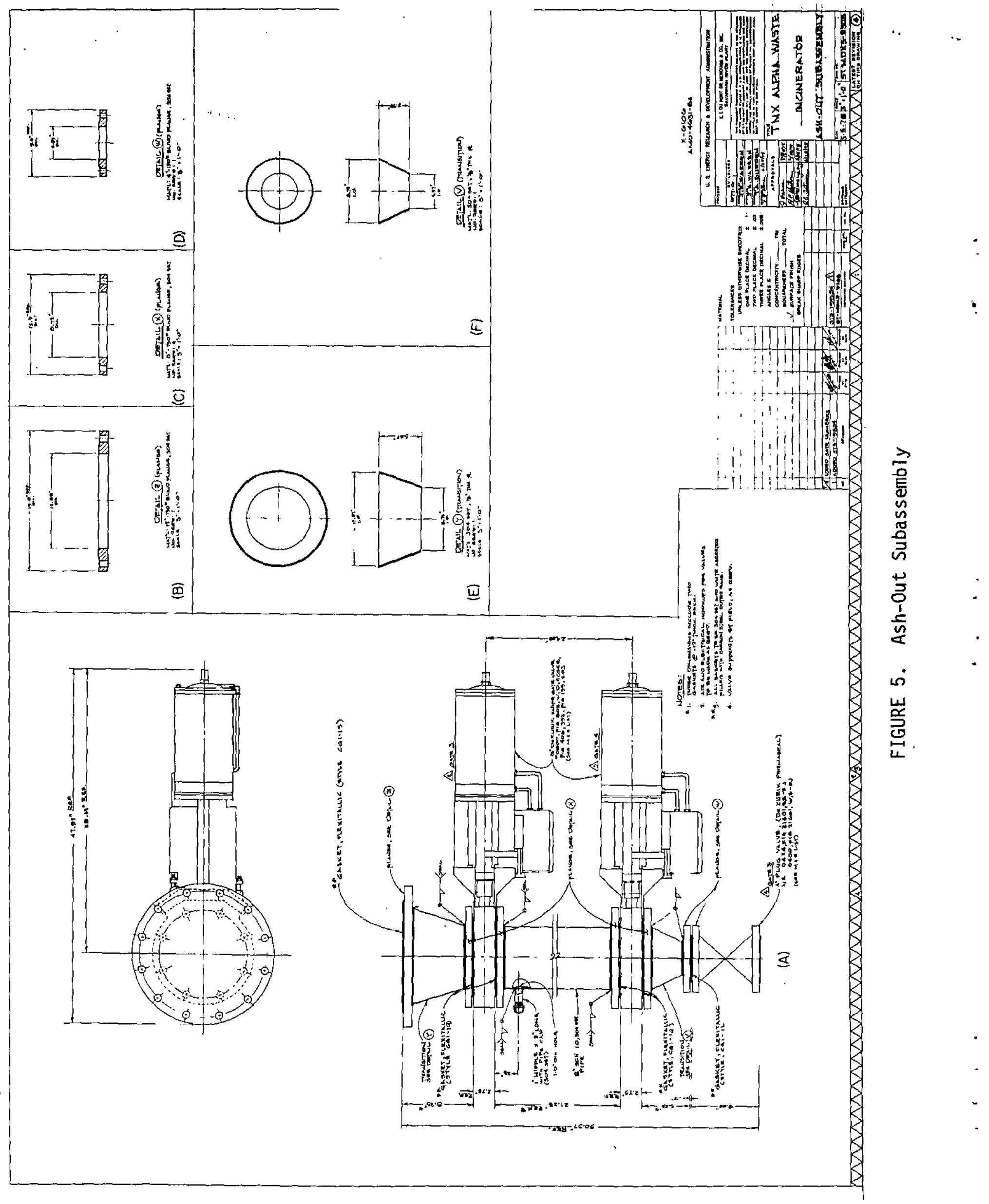




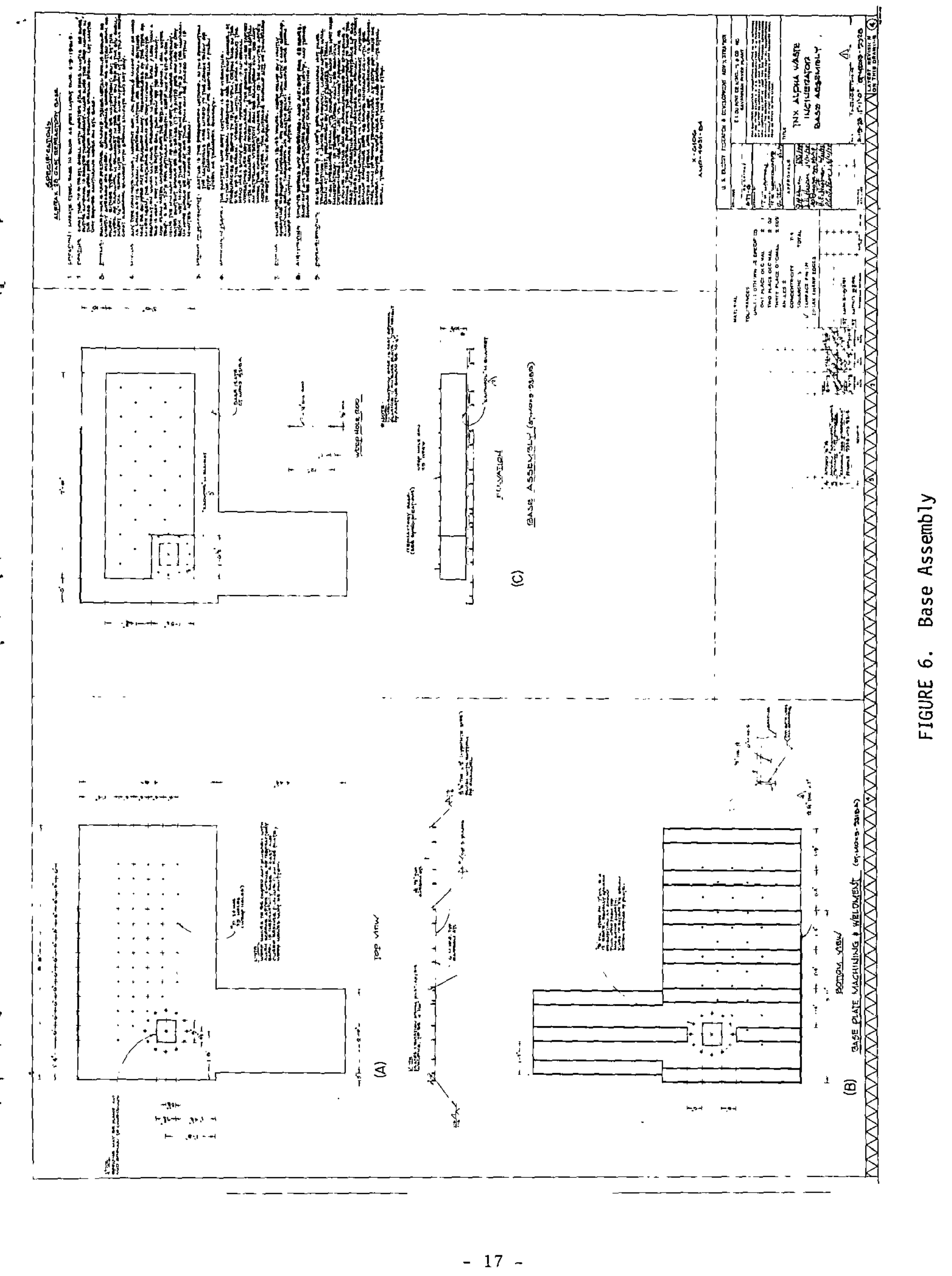


from the bottom knife valves by an operator from the pit where all the valve opening switches are located. The ash is then placed into any convenient container for further testing and evaluation. Should it be desirable to connect a vacuum system to the ash-out assembly so that entering the pit is not required, a capped pipe nipple has been installed in the side of the pipe between the two knife valves. This tap should be valved and opened during the vacuuming operation for venting purposes.

\section{Afterburner Gas Inlet}

The pyrolysis gas enters the afterburner and is mixed with up to $200 \%$ excess air in the air mixer shown in Figure 2 and detailed in Figure 7. This air mixer is made of Incone ${ }^{*} 625$ in order to withstand $1000^{\circ} \mathrm{C}$ and the corrosive pyrolysis gases. It rests on the ledge on the top of the primary inlet chamber (Figure 4). The 8.078-in.-diameter burner allows for expansion in the 8.5 -in. inside diameter tube when exposed to $1000^{\circ} \mathrm{C}$. Air enters the burner through three 3/4-in. Sch 40 Type 304L stainless steel pipes (Figure 2b). Three 1.5-in. holes are cast in the ceramic tube (Figure 8a) and heaters (Figure 9d) surrounding the burner and are aligned with the center of the burner holes for the air pipes. The gaps between the 1.5-in. holes in the afterburner tube and the air pipes are packed with Fiberfrax rope dipped in alumina silicate cement to reduce leakage. The stainless stee 1 pipes from the burner exit through the steel shell, and the shell is sealed with Fiberfrax packing as shown in Figure 2c. These pipes are then joined to a 2 -in. stainless steel line which has a bellows connection to allow for expansion of the pipes and burner as shown schematically in Figure 10. A $25-\mathrm{kW}$ air preheater is provided in the air entrance line to preheat the incoming air.

A flame must be maintained over the entire operating range of pyrolysis gas rates and compositions as a primary requirement of the incinerator burner. The flame is needed to enhance the reaction rate in the afterburner. Pyrolysis gas compositions are expected to vary over a wide range depending on the substances undergoing pyrolysis. The gas flow rates also vary, depending on the charged material and the temperatures inside the pyrolysis chamber.

Tests were run on several burner configurations with industrial grade methane. During observation of the flame for blowback (starting to burn below the burner in the region of the primary gas supply), the gas and air flows were monitored and varied. The design shown in Figure 7 was chosen because the flame did not blow back under any air-to-fuel ratios. Blowback normally produces a "popping" effect that is undesirable in the incinerator because

* Trademark of Huntington Alloys, Inc. 


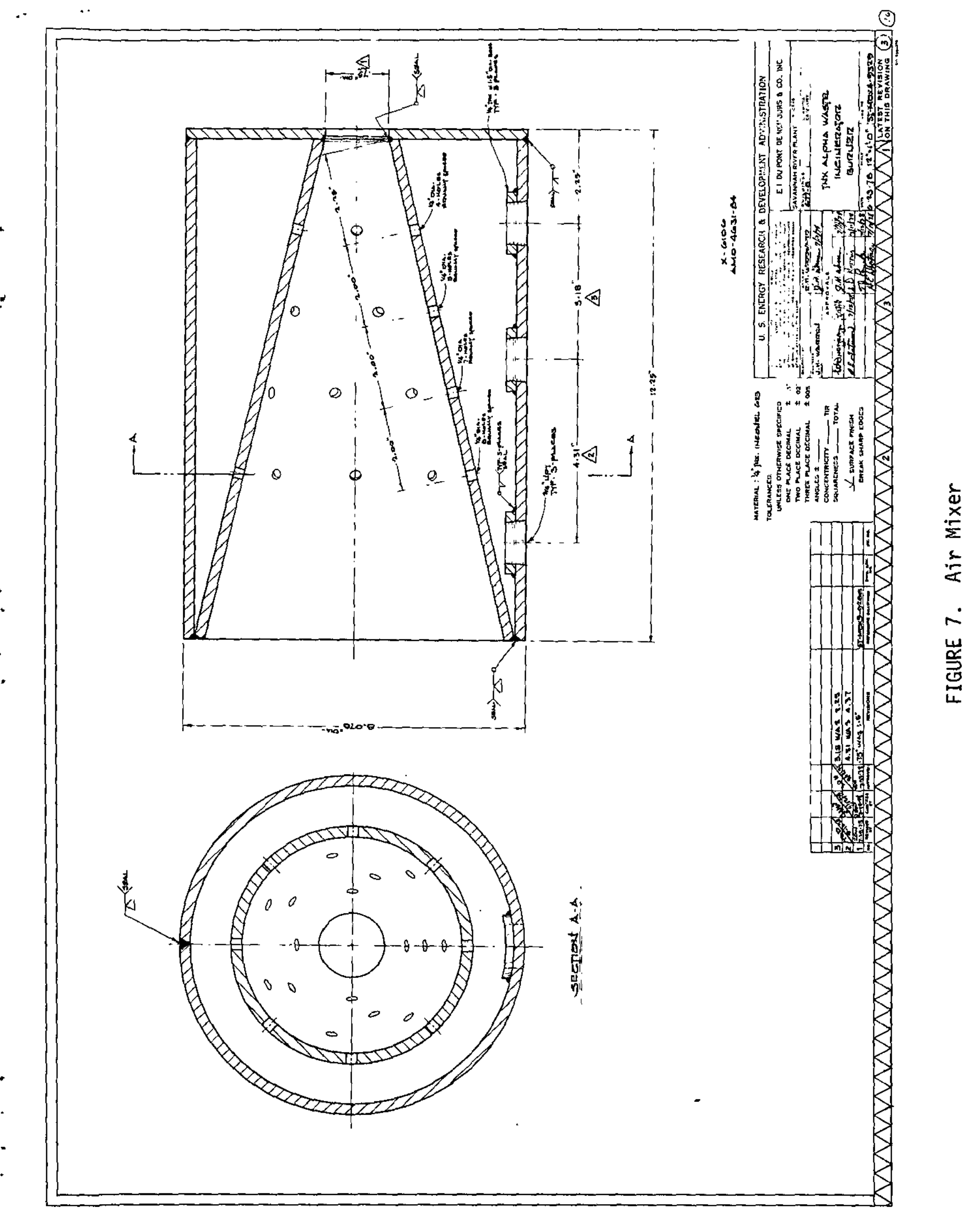




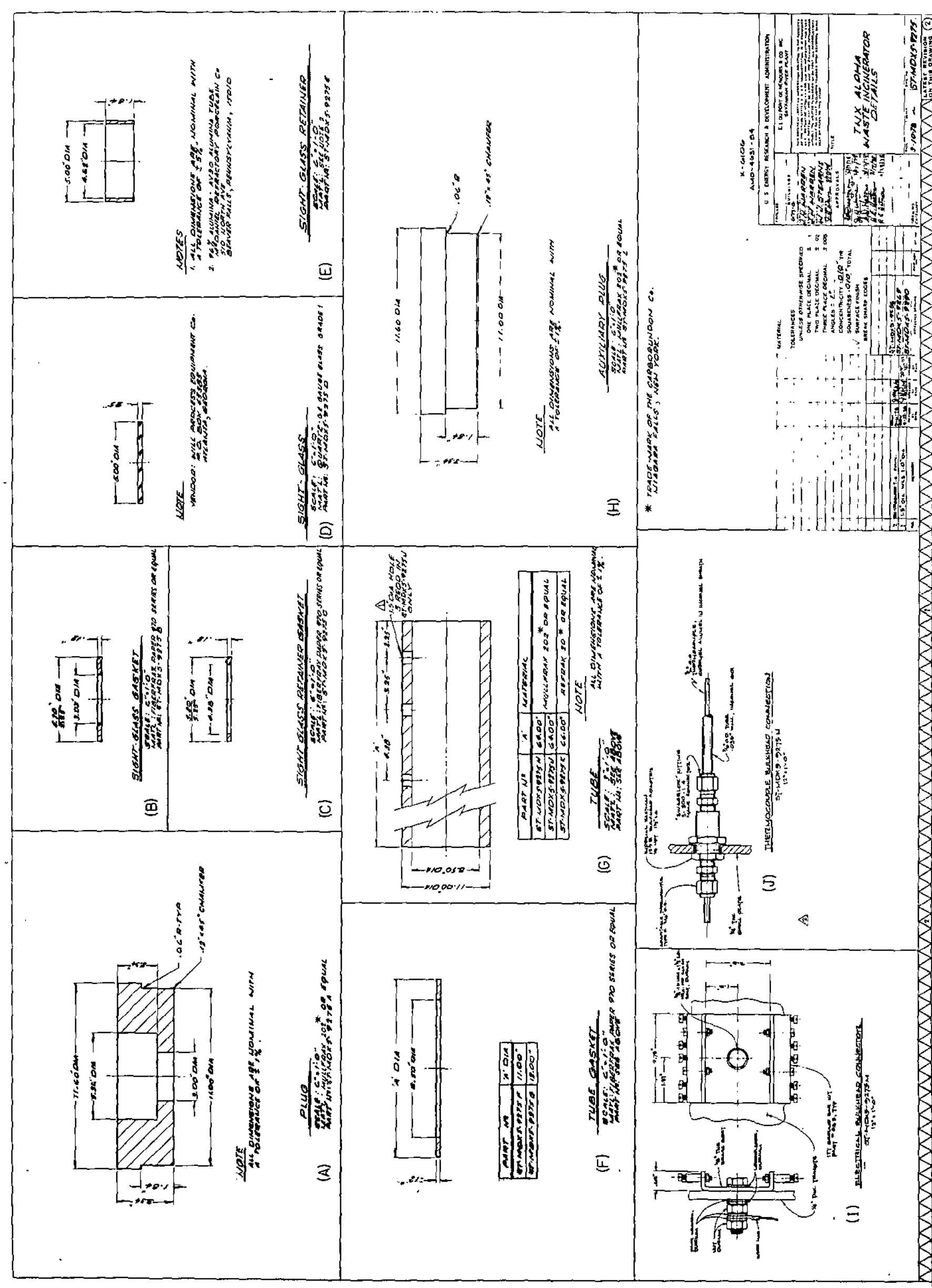

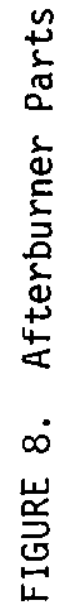




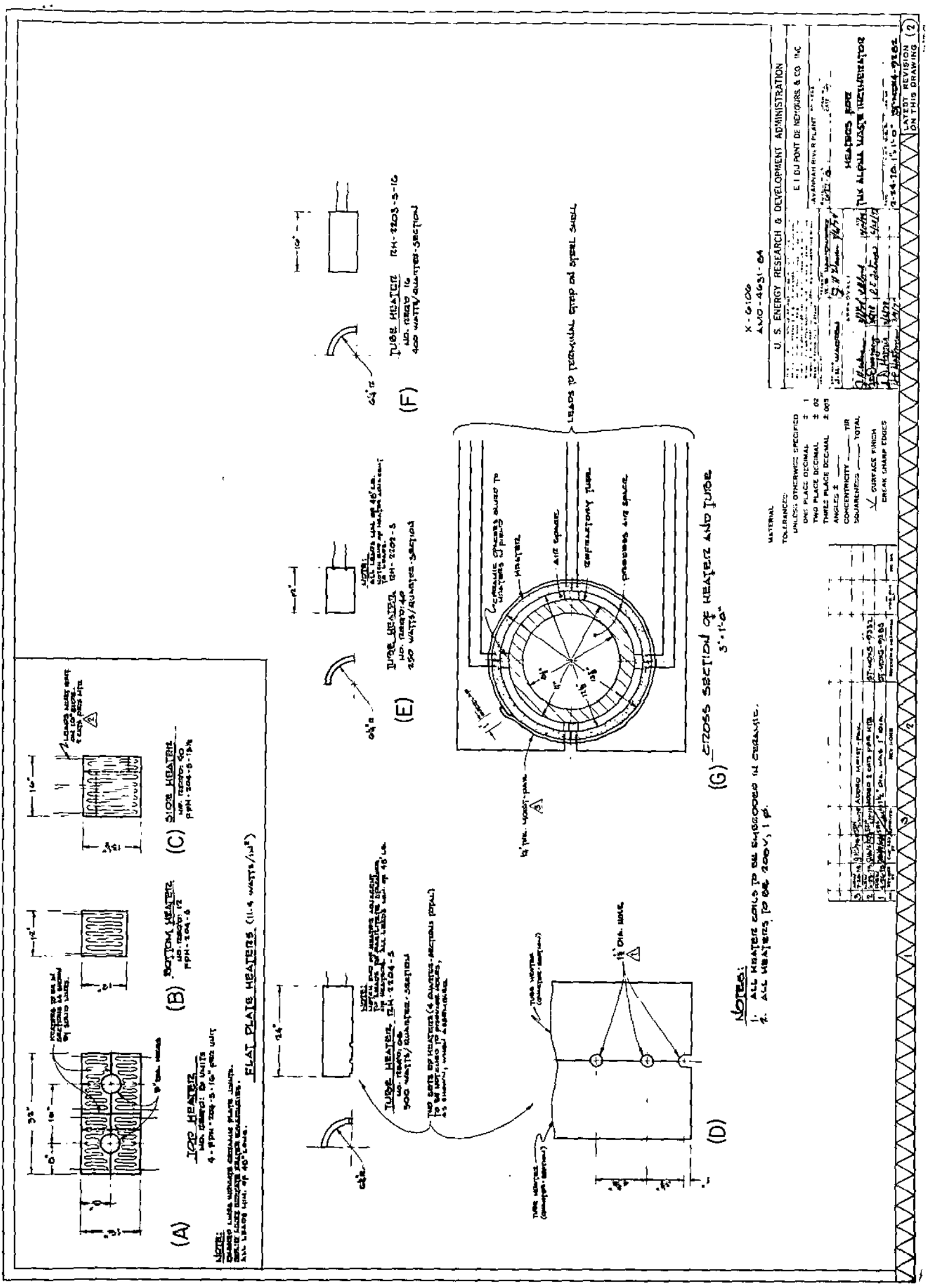




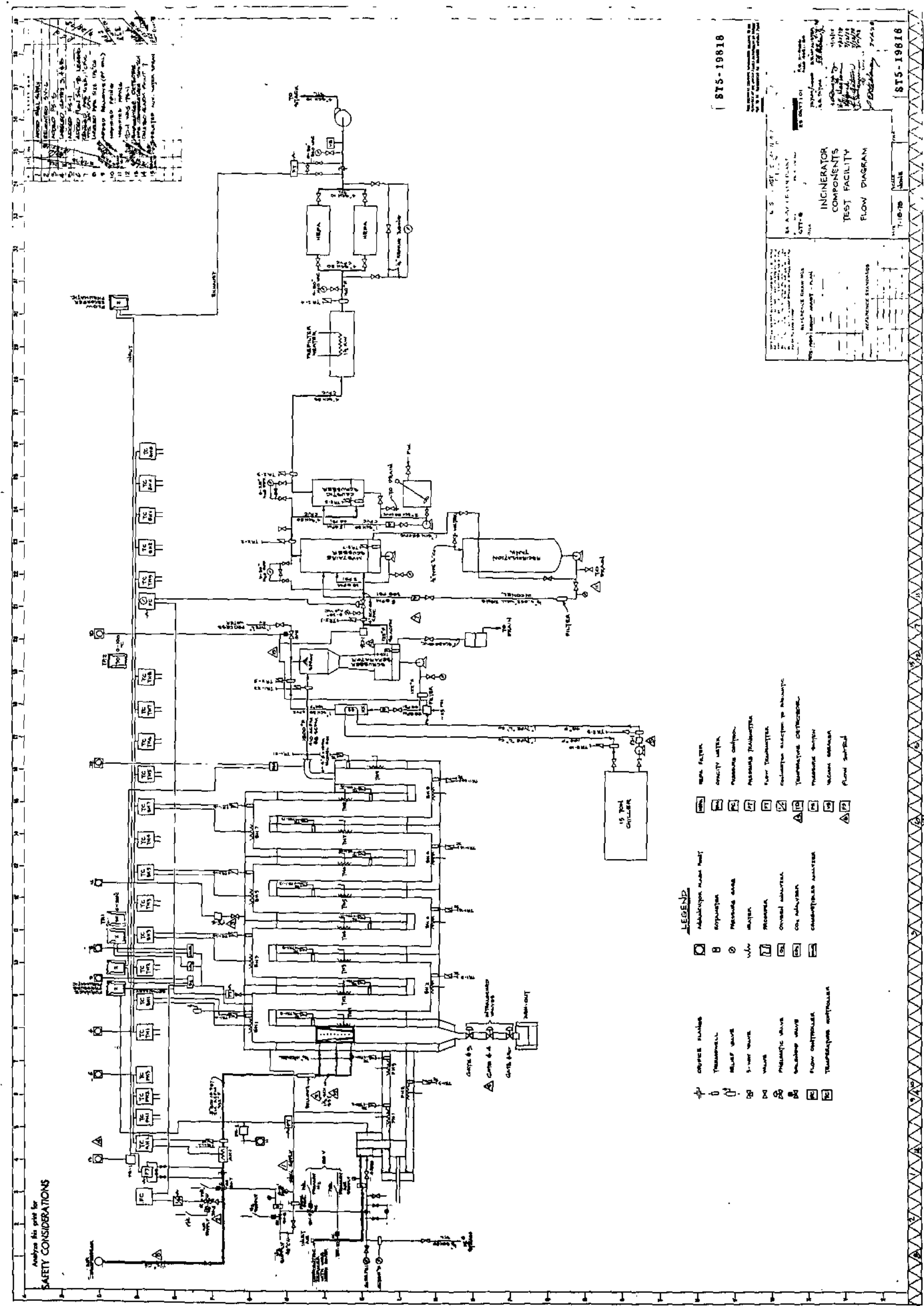


the mild shock waves created by the popping may eventually produce cracks and leaks. A1so, the shock waves may stir up the ash in the primary chamber and ash-out subassembly and promote ash entrainment into the off-gas.

Normally, a rich mixture (ratio of fuel to air is greater than one) ignites most easily. The burner being used creates a rich burning flame at the burner throat by the addition of excess air passing through a number of 0.25-in.-diameter holes. The 0.25 -in.-diameter air jets blowing into the cone act as flame holders and also tend to keep the flame off the metal, thus reducing its temperature and consequent thermal stresses. Air flow to the burner can be controlled to maintain a constant air-to-fuel ratio in the burner by the oxygen analyzer at the top of the second afterburner tube (Figures 2 and 3 ).

Replacement of the burner is accomplished by removing the plug in the top of the manifold above the first afterburner tube. (Full-scale tests on different burner configurations may be desired.) A burner may also be designed which uses only two of the three holes in the ceramic tube for the air inlet pipes. The third hole could then be used for a spark discharge system as an option if required to maintain the flame. A spark discharge system may be hard to maintain in a contaminated environment and should be omitted if possible.

\section{Afterburner}

\section{General Description}

The afterburner chamber is made of nine Cerox $700 \quad(90 \%$ alumina) tubes (Figure $8 \mathrm{~g}$ ) with each pair of tubes connected in series by a Cerox 700 cast manifold (Figure 11a) to form a labyrinth (Figures 1 and 2). Cerox 700 (90\% alumina) was chosen instead of Refrax 20 (SiC) because Refrax oxidizes at 1600 to $1900^{\circ} \mathrm{F}$. The two tubes being connected are compressively sealed with a Kaowool paper gasket and 3/8-in.-diameter Fiberfrax rope packing, which is dipped in alumina silicate cement before installation. Free-standing tubes and the independent end manifolds compensate for thermal expansion effects. A removable port allows vacuum cleaning of the afterburner, inspection of tube integrity, and insertion of an exhaust tube to test the effect of varying afterburner volumes (hence gas residence time) on exhaust gas particulates. The removable port contains a 5 -in.-diameter quartz sight glass for observation of incineration during operation. The manifold is too large to cast and cure as a unit and is cast in three pieces with shiplap joints in each section, and the entire unit is mortared together as shown in Figure 11b. Detailed design drawings of the manifold parts are shown in Figures 8 and 12. Each afterburner tube has a volume of $2.1 \mathrm{ft}^{3}$. The residence 


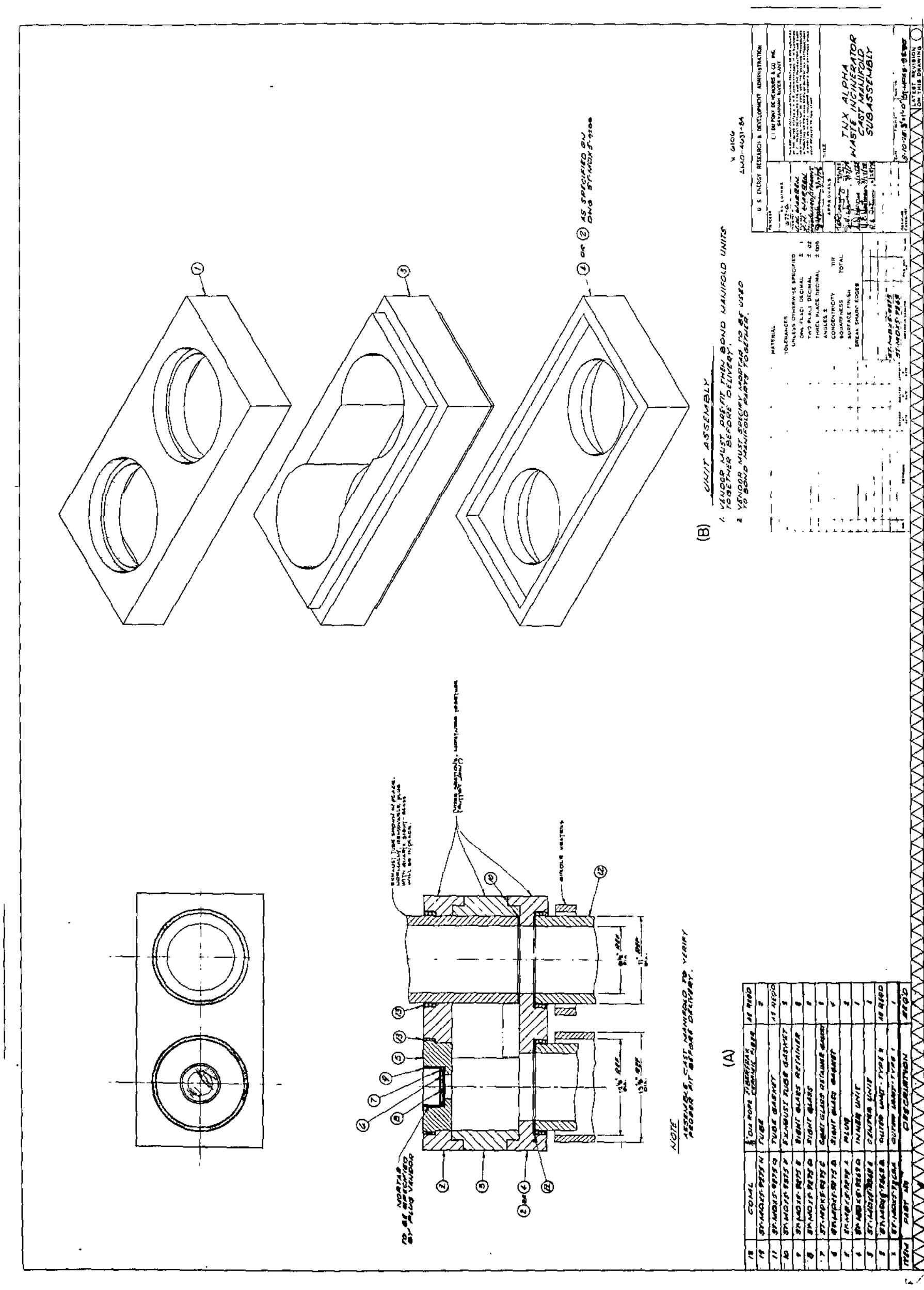




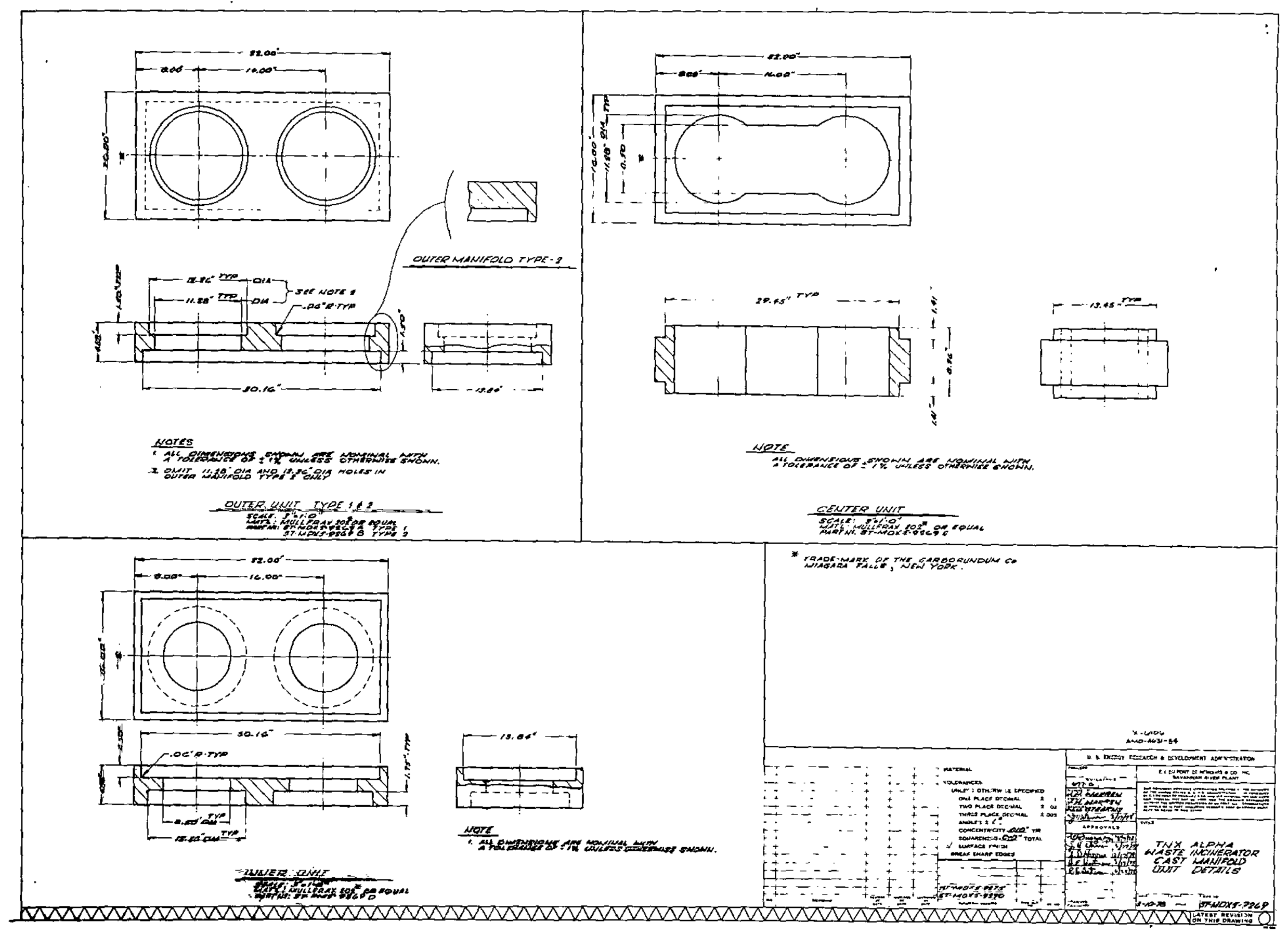

FIGURE 12. Cast Manifold Unit Details 
time in the afterburnex of the pilot incinerator described in Reference 1 was one-third that calculated for plug flow (plug flow $=$ volume $\div$ flow). With this result, the residence time for the $29.4 \mathrm{ft}^{3}$ afterburner is calculated to be $2.9 \mathrm{sec}$ for a flow of $205 \mathrm{ACFM}$ at $1000^{\circ} \mathrm{C}$. In the pilot incinerator, the flow was laminar; however, in the full-scale incinerator at 205 ACFM at $1000^{\circ} \mathrm{C}$, the Reynold's number is 3300 , which is in the transaction zone from laminar to turbulent flow. If the flow is turbulent, the pilot incinerator residence time results are conservative by as much as a factor of three, and the residence time may be as large as $8.7 \mathrm{sec}$.

The afterburner residence time is needed for oxidation of slow burning carbon particles which exit the flame present in the first afterbumer tube. The exact residence time required for complete oxidation of these particles is not known. Large residence times require large afterburner volumes which increase the size, cost, and maintenance problems of the incinerator; residence times that are too short cause excessive off-gas system contamination, reduce the incinerator waste volume reduction, and increase the maintenance costs. To experimentally determine the residence time required to completely oxidize the carbon particles, the afterburner volume was made variable. The cast manifolds are designed so that the removable plugs can be replaced with exhaust tubes (Figures 11 and 13). An exhaust tube placed in the manifold as shown in Table 1 can change the afterburner volume and gas residence time. The pressure drop in the manifold was calculated to be insignificant $\left(<0,01\right.$ in $\left.\mathrm{H}_{2} \mathrm{O}\right)$ for $205 \mathrm{ACFM}$ at $1000^{\circ} \mathrm{C}$. If more turbulence in the manifold is desired, one or more $S R-90^{*}$ firebricks may be placed in the manifolds to reduce the 8.5-in. crossover between the tubes.

\section{Heaters}

Heater requirements for the afterburner were calculated on the basis of the amount of time required to heat the incinerator to $1000^{\circ} \mathrm{C}$ in $10 \mathrm{hr}$. A specific heat of $0.24 \mathrm{Btu} /\left(1 \mathrm{~b}_{\mathrm{m}}\right)\left({ }^{\circ} \mathrm{R}\right)$ was used for the Cerox parts. For the 8.5-in.-inner diameter $\times 11.0$-in. outer diameter $\times 64$-in.-long tube weighing approximately $250 \mathrm{lb}$, the heat requirement is $3.0 \mathrm{~kW}$. For conservatism and possible later changes in the experimental program requiring a larger heat input, $5.0 \mathrm{~kW}$ was provided. For the manifolds weighing approximately $550 \mathrm{1b}$, the required heat input is $6.7 \mathrm{~kW} ; 11.0 \mathrm{~kW}$ is provided.

A cross section of the tube heater is shown in Figure 9. The inside diameter of the heater is $12.125 \mathrm{in}$. which leaves a $9 / 16-i n$. air space on the outside of the 11.0-in. tube. Variations in the refractory tube composition may result in hot spots in the heater, if the tube and heater contact one another; therefore,

\footnotetext{
* Trademark of The Babcock \& Wilcox Co.
} 

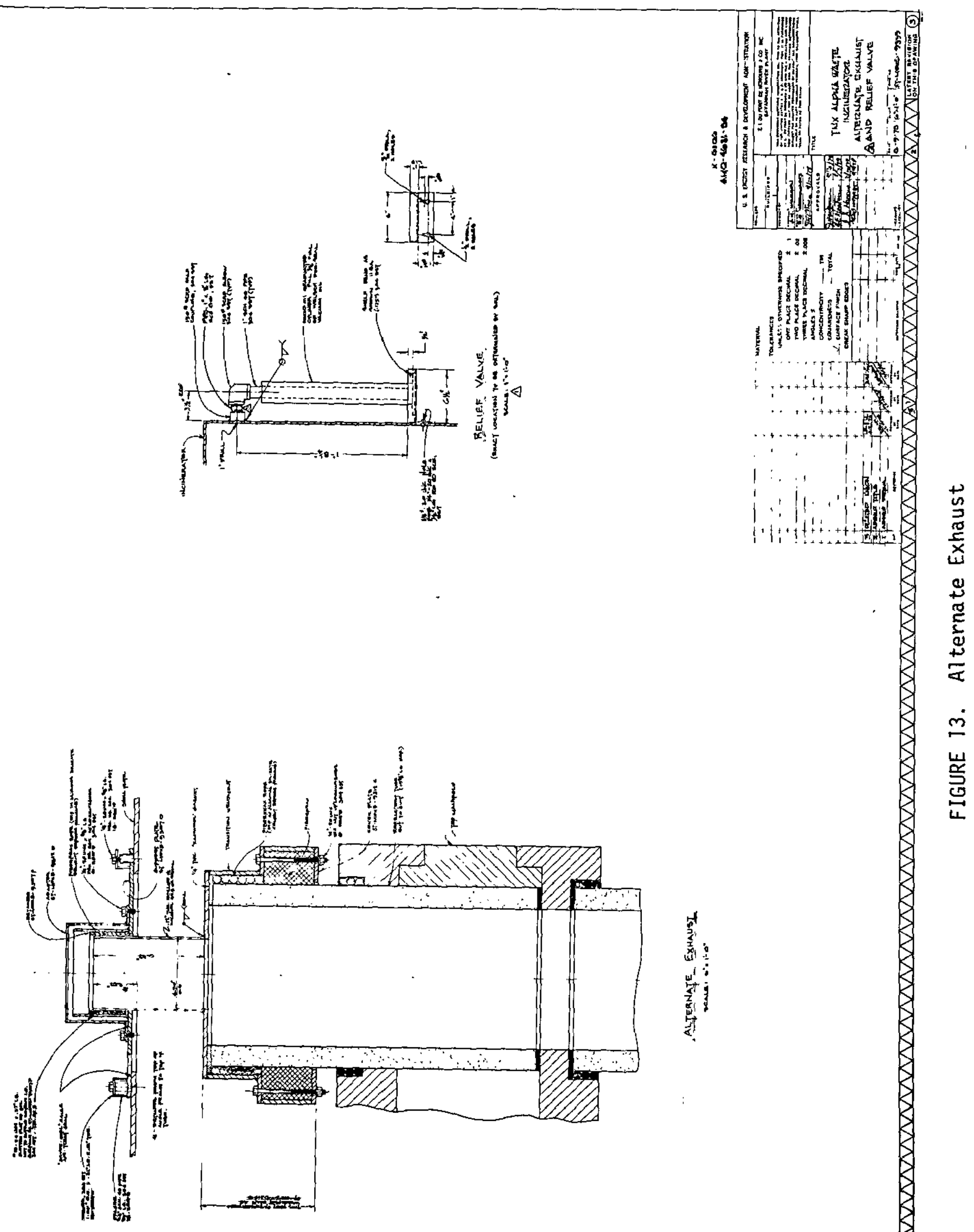


\section{TABLE 1}

\begin{tabular}{|c|c|c|}
\hline $\begin{array}{l}\text { Exhaust Tube } \\
\text { Position, End } \\
\text { of Tube Number }\end{array}$ & $\begin{array}{l}\text { Afterburner } \\
\text { Volume, } f t^{3}\end{array}$ & $\begin{array}{l}\text { Residence Time } \\
\text { for } 205 \mathrm{ACFM} \\
\text { at } 1000^{\circ} \mathrm{C} \text {, sec }\end{array}$ \\
\hline 1 & 2.2 & 0.2 \\
\hline 3 & 9.0 & 0.9 \\
\hline 5 & 15.8 & 1.5 \\
\hline 7 & 22.6 & 2.2 \\
\hline 9 & 29.4 & 2,9 \\
\hline
\end{tabular}


this air space should maximize heater life. Ceramic spacer blocks are used to maintain this air space. Holes cut in one set of heaters allow for the air pipes to exit the first afterburner tube (Figure 9). The heaters are shown assembled around the tubes in Figure 2. For the 66-in.-long tubes, two 24-in.-long heaters and one 12-in. heater are used to supply $5.0 \mathrm{~kW}$ of heat. Notches are cut in the top of the heaters to allow the heater lead wires to exit without interference. The tube heaters are held around the tube with Moist Pak $D^{*}$ blanket material.

Figures $3 a$ and $3 b$ illustrate the side heater installation. Each manifold has a different number of heaters; therefore, the heaters are installed with a constant heat flux per unit area of 11.4 watts/in. ${ }^{2}$ so that the minimum area times the heat flux equals $11.0 \mathrm{~kW}$. The different number of heaters results in inputs of 11.0 to $20.0 \mathrm{~kW}$ per manifold.

The heaters on top of the top manifolds contain a 5-in.diameter hole for viewing the process through a quartz window in the removable plug. The plug (Figure $8 \mathrm{a}$ ) contains a 3-in.-diameter hole with a 1.0-in. 1ip for the glass (Figure 8d) and associated gaskets (Figures $8 b$ and $8 \mathrm{c}$ ) to rest on. The glass is held in place by an alumina sight glass retainer (Figure $8 \mathrm{c}$ ) and is mortared in place as shown in Figure 11a. The heaters under the bottom manifolds are $12 \times 12 \mathrm{in}$. and are removable between the $4 \times 4 \times 1.5$-in.-thick pillars supporting the bottom manifold. A11 of the heaters are controlled by proportional controllers which have a high-temperature cutoff and a current limiter to control the rate-of-temperature rise.

The rate-of-temperature rise in the refractory during the startup is limited to $100^{\circ} \mathrm{C} / \mathrm{hr}$. The temperature measurements for the temperature controllers are monitored by chromel-alumel thermocouples in Inconel sheaths with the monitoring tips located in the air spaces between the tubes or manifolds and the heaters. Figure 3 shows the location of the top and bottom thermocouples, and Figure 14 shows the location of the tube thermocouples.

The thermocouples are inserted in a thermowell of 5/16-in.outside diameter 304L stainless steel tubing and a bulkhead connector (Figure 8j) through the steel she11. This thermowell allows for removal of the thermocouples if failure occurs. Each thermocouple sheath contains two thermocouples, one to be used on the recorder and one for control purposes.

The side heaters on the bottom manifolds are supported at the bottom by the 4-in.-square pillars and at the top manifold by the Incoloy ${ }^{* *} 800 \mathrm{H}$ heater straps detailed in Figure $15 \mathrm{c}$. The

\footnotetext{
* Trademark of the Carborundum Co.

** Trademark of Huntington A1lays, Inc.
} 

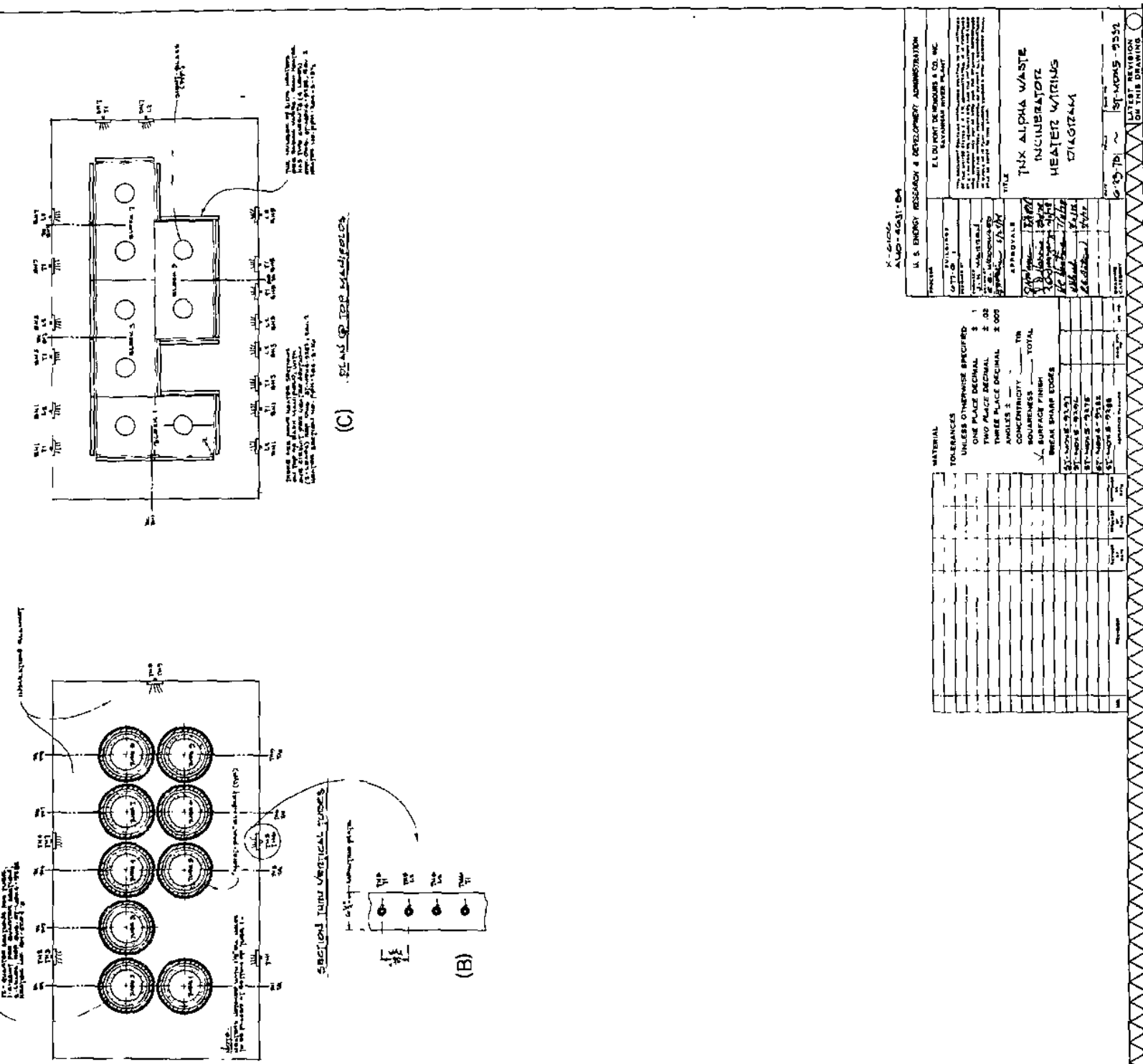

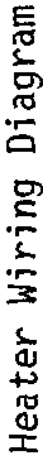
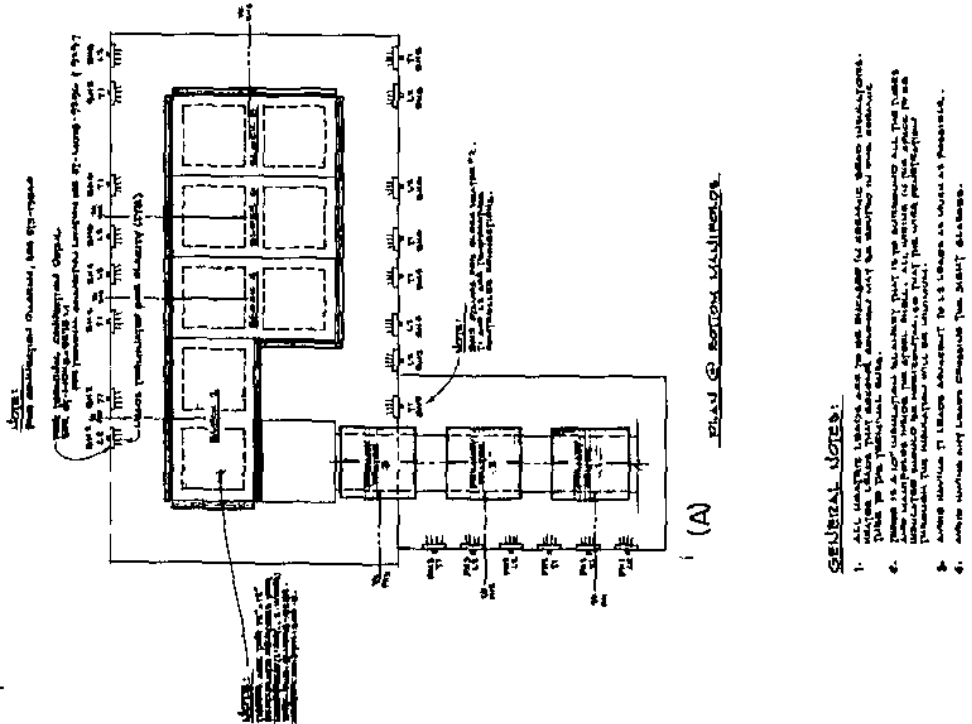


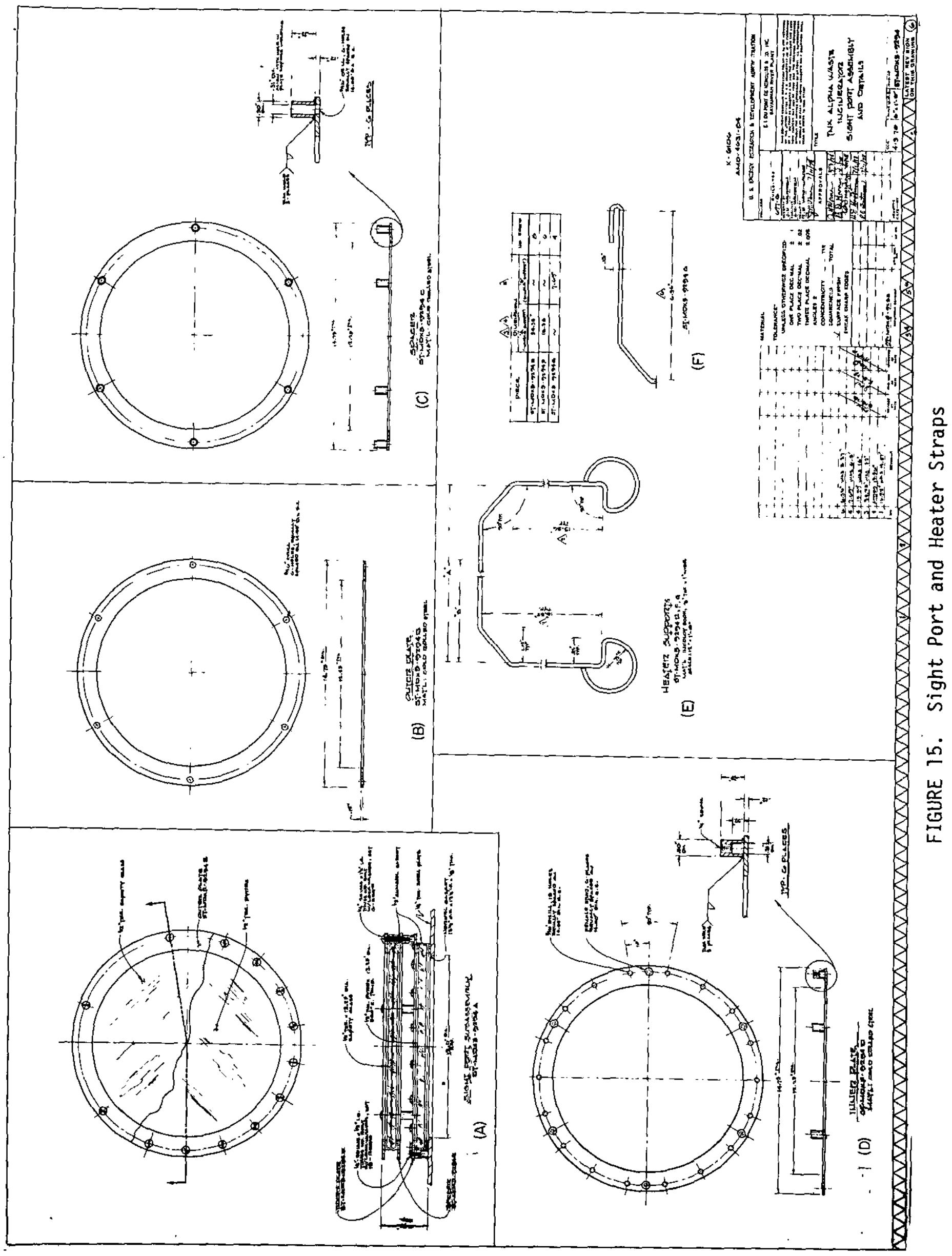


side heaters weigh $16 \mathrm{lb}$ each. With two straps per heater, the maximum stress from bending is calculated to be $1625 \mathrm{psi}$ at the botton of the strap where the heater rests. The circular bend at the bottom of the strap is added to put this part in compres sion and, therefore, reduce the bending stress to less than $500 \mathrm{psi}$. Incoloy $800 \mathrm{H}$ was chosen for the heater straps because of its creep resistance. At a stress of $1000 \mathrm{psi}$, the creep rate is $0.09 \% / 1000 \mathrm{hr}$ at $1800^{\circ} \mathrm{F}$. The rupture life at $1000 \mathrm{psi}$ and $1800^{\circ} \mathrm{F}$ is $24,000 \mathrm{hr}$. For the $1 / 8$-in.-thick by 1 -in.-wide straps supporting one-half of the $16-1 \mathrm{~b}$ side heaters, the normal stress is less than $100 \mathrm{psi}$. Because the bending stress is less than 500 psi, the projected $2-y r$ life based on the 1000 psi creep data is conservative. The incinerator is expected to run for approximately $2 \mathrm{yr}$ or $20,000 \mathrm{hr}$ and therefore, a rupture 1 ife of 24,000 $\mathrm{hr}$ is acceptable. Based on the creep rate of $0.09 \% / 1000 \mathrm{hr}$, at the end of $20,000 \mathrm{hr}$, the total creep will be $1.8 \%$. The total creep of $1.8 \%$ indicates that the top of the straps that are 24.64 in. long will be 25.36 in. long at the end of $20,000 \mathrm{hr}$ and the sides that are 16.52 in. 1ong will be 16.82 in. long at the end of $20,000 \mathrm{hr}$. Neither of these results should affect the heater performance. The effect from the creep of the 16.82-in. length is the drop of the heater down on the side of the manifold 0.3 in. which should have no effect on the heater performance. The heater strap is 16.52 in. long on the side so that after thermally expanding, due to the 70 to $1800^{\circ} \mathrm{F}$ temperature rise, the heater will be at the bottom of the also expanding Cerox manifold.

\section{Steel Base and Foundation}

The incinerator base assembly (Figure 6) is made from 0.5in.-thick carbon steel plate welded to 6-in. channels weighing $10.5 \mathrm{lb} / \mathrm{ft}$. The channels are directly under the center of each pair of tubes and manifolds in the afterburner and under the center of the primary chamber tube as shown in Figure 2. These channels are added to increase the rigidity of the base and also to allow air to circulate between the steel base and the concrete floor.

The steel base is coated with Foster Stackfas Mastic* to prevent corrosion from $\mathrm{HC} 1$ condensation. A 0.5 -in.-thick layer of Kaowool-M board coated with sodium silicate is on top of the base plate as an added insulation over which a 10-in. layer of Alfrax ${ }^{* *} B I$ No. 28, a fused aluminum oxide bubble castable, is

* Trademark of the Foster Division, Amchem Products Co., Anbler, $\mathrm{Pa}$.

** Trademark of the Carborundum Co. 
poured. The bubble castable was chosen for its semi-insulating properties and relatively high compressive strength. The compressive strength of the Alfrax is 1000 to $1300 \mathrm{psi}$ at $225^{\circ} \mathrm{F}$, 450 to $600 \mathrm{psi}$ at $1500^{\circ} \mathrm{F}$, and 900 to $1200 \mathrm{psi}$ at $2500^{\circ} \mathrm{F}$. The maximum compressive stress on the castable is the weight of the top manifold (501 lb), the bottom manifold $(520 \mathrm{lb})$, and two tubes $(496 \mathrm{lb})$ divided by the $48-$ in. $^{2}$ area or the equivalent of three $4 \times 4$-in. pillars supporting them. This stress is approximately 32 psi and much less than the lowest castable compressive strength of $450 \mathrm{psi}$.

Forced drying of the cast refractory was required to remove the water in the cast refractory base before assembly of the incinerator. The specification for this dry out (Figure 6) called for forced drying at $200^{\circ} \mathrm{F}$ for at least $48 \mathrm{hr}$. The cast base contained approximately $1300 \mathrm{lb}$ of castable containing 2-3/8 gal of water per $100 \mathrm{lb}$ of castable or approximately 31.0 gal of water which had to be removed. Weep holes (Figure 6c) were located in the steel to allow the water to escape. These holes were plugged with allen screws to maintain the airtight steel shell after the forced drying took place. Curing of the refractory base occurs when the incinerator is elevated to normal operating temperature.

\section{Steel she I2}

The entire refractory assembly (primary and afterburner) is enclosed in an angle iron frame with 0.25 -in.-thick plates bolted to the she1l. Electrical connections from the heaters are made through the steel shell by bulkhead connectors (Figure $8 i$ ) on 5-in.-wide strips made of National Electrical Manufacturers Association Grade G-7 continuous filament glass cloth. The cloth is bonded with silicone resin. The heaters are wired in parallel with two pairs of leads exiting the steel shell per manifold and one pair per tube as shown in Figure 14. Exact locations of the connectors for the wires are indicated by the holes in the NEMA G-7 strips. All of the electrical connections through the she11 are covered by a closed metal shield to which external wiring is connected by conduit from overhead trays.

The top plates are mounted on removable angle iron braces to allow for overhead crane removal of the cast manifolds and tubes. The top plates contain 12-in.-diameter holes for removal of the cast refractory plugs in the top manifolds. The holes are normally covered with two sight glasses (one above the other) (Figure 15) which are used for viewing the incineration process. The bottom sight glass is made of 1/2-in.-thick Pyrex* glass that

* Trademark of The Corning Glass Co. 
withstands temperatures up to $500^{\circ} \mathrm{C}$. Although the she 11 is not assumed to be $500^{\circ} \mathrm{C}$, radiation from within the refractory tubes could produce temperatures too hot for the upper $1 / 2$-in.-thick safety glass installed for its nonshattering properties. A 1/2-in.-thick air space is provided between the two glasses to allow for convective cooling. A U-shaped rubber gasket is to be used to provide the seal around the glasses. For the bottom Pyrex glass, a $1 / 8$-in.-thick Norde ${ }^{*}$ gasket is also added between the steel shell and the U-shaped gasket. The Nordel gasket will withstand temperatures up to $250^{\circ} \mathrm{F}$. The $1 / 2$-in.-thick glass is designed for pressures up to 5 psi inside the steel shell.

One purpose of the steel shell is to provide an airtight containment around the ceramic parts since leakage in ceramic joints is probable. Silver Seal, ${ }^{*}$ a plastic sealing product, is used between the angle iron and the steel frame. It is effective to $1500^{\circ} \mathrm{F}$ and is supposed to flow into and out of openings caused by weaving and breathing of joints from pressure and temperature. The inside of all the angle iron plates are coated with Foster Stackfas Mastic as previously mentioned for the base plate. The outside is painted with a heat resistant aluminum paint.

\section{Pressure Relief Valve}

A relief valve (Figure 16f) is installed through the steel shell directly into the afterburner and is designed to relieve at 0.25 psi. It is located in a $24 \times 24$-in. duct approximately five feet above the incinerator and is connected to the adapter (Figure 16) which is in the sight glass above the second afterburner tube (Figure 3 - tubes are numbered in terms of afterburner gas flow). The connection between the relief valve and the adapter is made by a $3-\mathrm{in}$. Sch 40 Type $304 \mathrm{~L}$ stainless steel pipe (Figure 16g).

The relief valve (Figure 16f) is made from a 6 -in.-long piece of $10-i n$. Sch 40 pipe with a plate welded in the bottom and a $45^{\circ}$ taper machined at the top. This taper and the relief valve lid are lapped to provide an airtight seal. The bottom plate is drilled and welded to a 3.0-in.-diameter Sch 40 pipe which leads to the afterburner. The area of the valve body is 84.7 in. ${ }^{2}$; therefore, the 1id weighs $21.2 \mathrm{lb}$. Tapers on the inside of the lid are designed to prevent sticking should the lid tilt during relief.

* Trademark of The Du Pont Co.

** Trademark of the Industrial Shim and Gasket Co. 


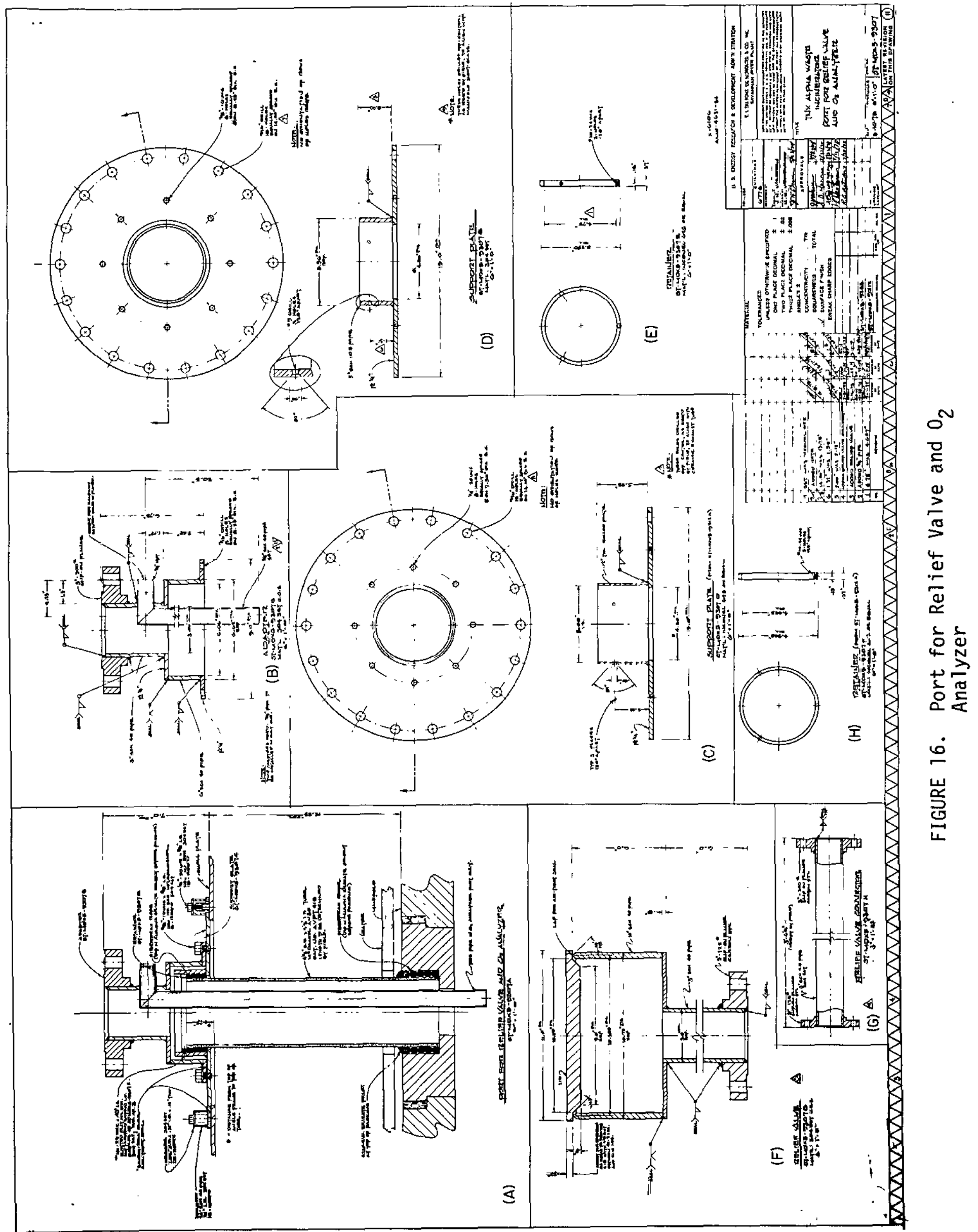


Normal operation of the incinerator is expected to have a flow of 205 ACFM at $1000^{\circ} \mathrm{C}$. The off-gas system is designed for twice the average flow or 410 ACFM. An air flow of 1000 ACFM was chosen for the relief valve design in order to be extremely conservative, because pressurization of the afterburner is not acceptable. The Mach number in the line to the relief valve must not be greater than unity because the flow is then compressible, and all of the pressure may not be relieved. To determine the Mach number, the gas in the line was assumed to be air, and the speed of air in the line was calculated along with the speed of sound at $1000^{\circ} \mathrm{C}$. For air at normal pressure, the speed of sound c was calculated by

$$
c=49.02 \sqrt{\mathrm{T}}
$$

where $c$ is in $\mathrm{ft} / \mathrm{sec}$ and $\mathrm{T}$ is the absolute temperature in degrees $\mathrm{R}^{3}$ Therefore, at $1000^{\circ} \mathrm{C}, c=2347 \mathrm{ft} / \mathrm{sec}$. For the 3 -in. Sch 40 pipe having an inside diameter of $3.068 \mathrm{in.}$, the pipe inlet velocity is $325 \mathrm{ft} / \mathrm{sec}$. Therefore, the Mach No. $M=v / c=325 / 2347=0.14$, well below unity.

The net effect of friction in the pipe, which joins the afterburner to the relief valve, is to reduce pressure in the direction of flow. The reduced pressure accelerates the gas so that the Mach number approaches unity. If unity occurs, the flow is limited (choked), and the pressure in the incinerator may not be completely relieved. The following equation ${ }^{3}$ was used to calculate the length of pipe ( $L_{\max }$ ) at which the frictional effects cause an acceleration so that the Mach number increases to 1 :

$$
4 \overline{\mathrm{f}} \frac{L_{\max }}{D}=\frac{1-M^{2}}{\mathrm{kM}^{2}}+\frac{\mathrm{k}+1}{2 \mathrm{k}} \text { 1n } \frac{(\mathrm{k}+1) M^{2}}{2\left(1+\frac{\mathrm{k}-1}{2} M^{2}\right)}
$$

where $\vec{f}=$ Fanning friction factor $=0.005$ for the 3 -in. pipe

$$
\begin{aligned}
& \mathrm{k}=\mathrm{c}_{\mathrm{p}} / \mathrm{c}_{\mathrm{v}}=1.318 \text { at } 1000^{\circ} \mathrm{C} \\
& \mathrm{M}=\text { initial Mach number }=0.14
\end{aligned}
$$

Solving Equation 2 yields $L_{\max } \simeq 440 \mathrm{ft}$. The distance from the inside of the afterburner to the relief valve is $7 \mathrm{ft}$, much less than the $440-\mathrm{ft}$ value for $\mathrm{L}_{\max }$. Shapiro ${ }^{3}$ notes that for short pipes, the average apparent friction coefficient may be substantially in excess of that given in the Moody tables; therefore, the $440-\mathrm{ft}$ value may actually be less. However, $\overline{\mathrm{f}}$ is not expected to be off more than a factor of 2; consequently, $\mathrm{L}_{\max }$ is still much larger than the actual pipe length. Based on these results, the incinerator air flow of 205 ACFM should be able to exit the relief valve pipe without compressibility effects. 
To determine the height to which the top of the valve would rise during the pressure relief, all of the pressure is assumed to be exerted instantaneously so that

$$
V_{2}=\sqrt{2 g_{c}} \overline{P_{1} / \rho}
$$

where $V_{2}$ equals the exiting velocity and $P_{1}$ equals the relief pressure of $0.25 \mathrm{psi}$. At $1000^{\circ} \mathrm{C}, \rho$ is $0.173 \mathrm{lb} / \mathrm{ft}^{3}$ and $V_{2}$ is calculated to be $366 \mathrm{ft} / \mathrm{sec}, V_{2}$ is used to solve for the area required to relieve $1000 \mathrm{ft}^{3} / \mathrm{min}^{2}$ and yields an area of $6.557 \mathrm{in} .^{2}$ For the relief valve, the area for this relief flow is the circumferential area between the body and the 1 id and is $A=\pi d h$ where $d$ equals the diameter of the taper on the relief valve body of $10.385 \mathrm{in}$. Solving this equation for $\mathrm{h}$, one finds that the height that the lid will rise is 0.2 in. To accommodate this height, a 0.5 -in.-deep inner ring was designed into the lid so that the lid does not slide off. When the pressure is relieved, the 1 id falls back down and immediately rises again creating a clatter noise similar to a typical pressure cooker. A door is installed in the exhaust duct for checking the relief valve, if it becomes cocked during a relief incident. The exhaust gases from the relief valve will exit through the $24 \times 24-i n$. overhead duct to the exhaust stack and exit to the atmosphere outside the building.

\section{Exhaust}

For the longest residence time, the afterburner exhaust leaves the ninth ceramic tubes through the 4-in.-diameter Inconel 625 transition piece (Figure 17). The 4-in.-diameter exhaust is acceptable for the 205 ACFM flow since the 3 -in.relief valve line was shown to be acceptable. Sealing is made by Kaowool gaskets and Fiberfrax rope and blankets as previously described for other ceramic-to-metal transition pieces. Thermal expansion is permitted at the slip joint at the steel shell exit. The 4.25-in.-diameter exhaust line going to the venturi quench is welded directly to the adapter on the outside of the stee1 shell (Figure 2).

\section{Loading Assembly}

The incinerator metal loading assembly (Figure 18) inserts cylindrical packages of paper waste into the primary chamber, both automatically and safely, and maintains a vacuum of up to 15 to $20 \mathrm{in}$. of $\mathrm{H}_{2} \mathrm{O}$ in the primary chamber. Eighteen $300-\mathrm{g}$ waste packages, for a nominal one-hr run are placed in the aluminum rotary feed magazine (Figure 19). The magazine rotates on top of an aluminum base plate (Figure 18). The packages fall through a hole in the base plate into the loading assembly body. The 


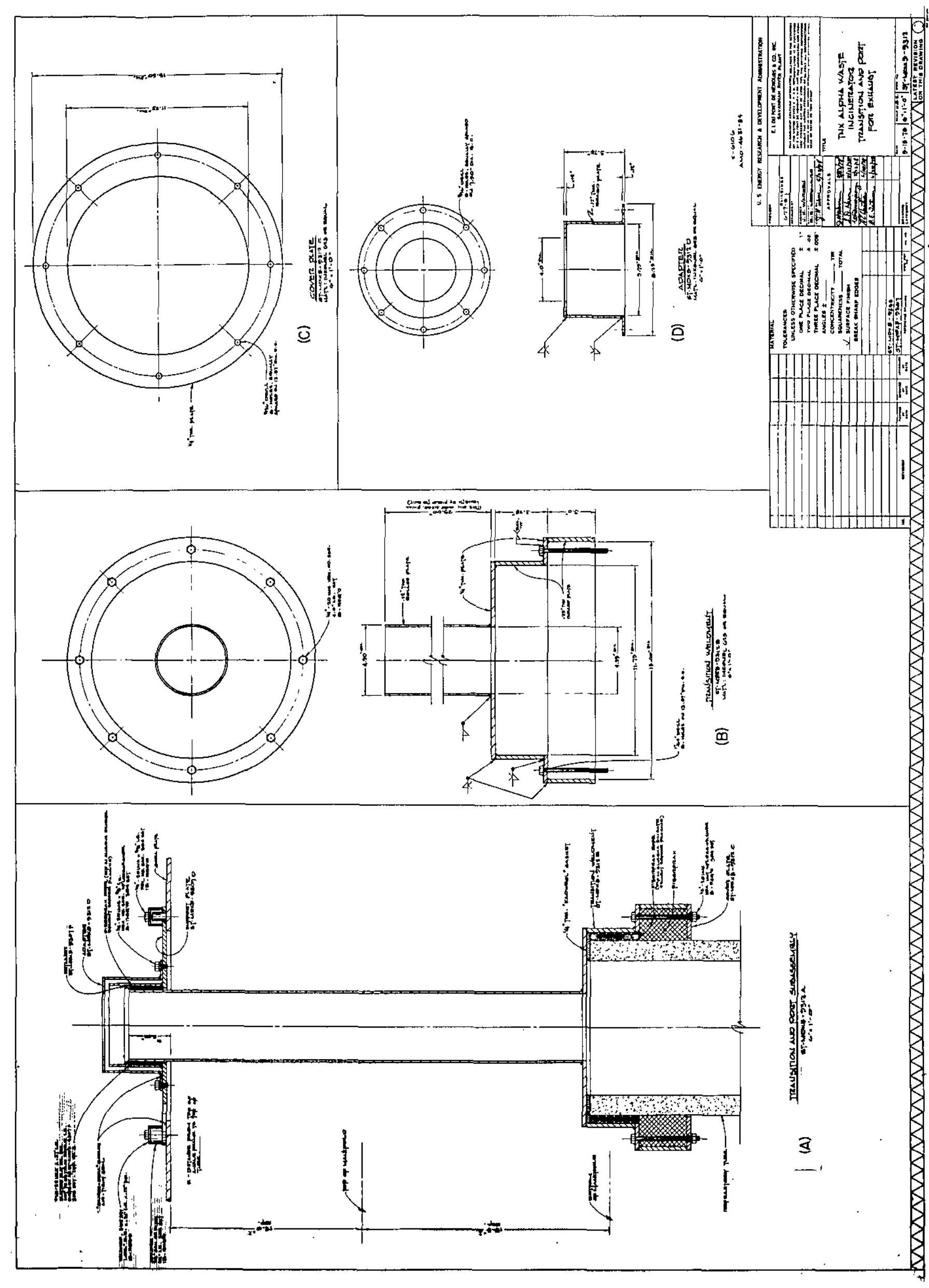

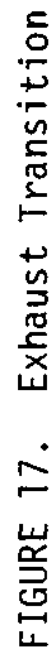




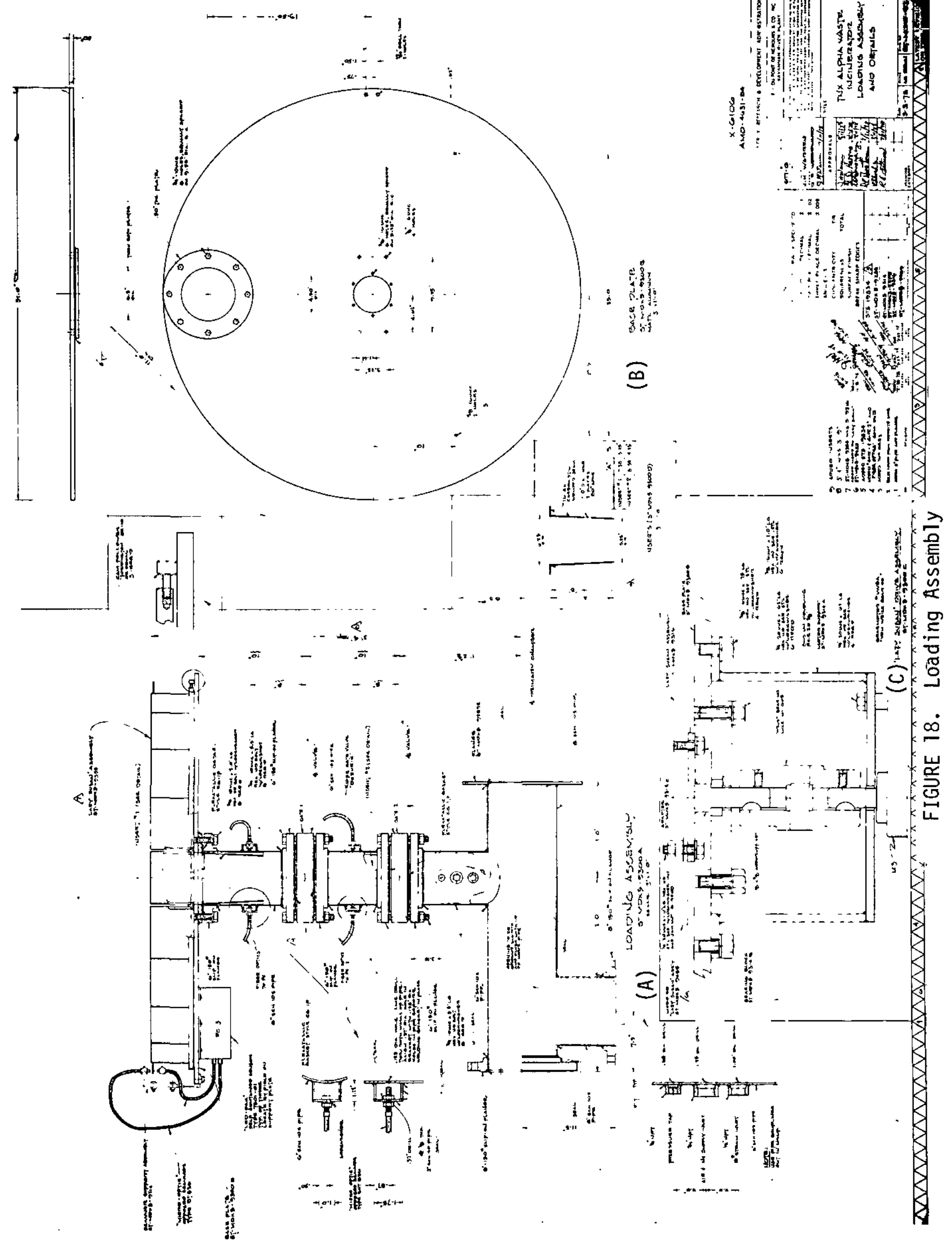




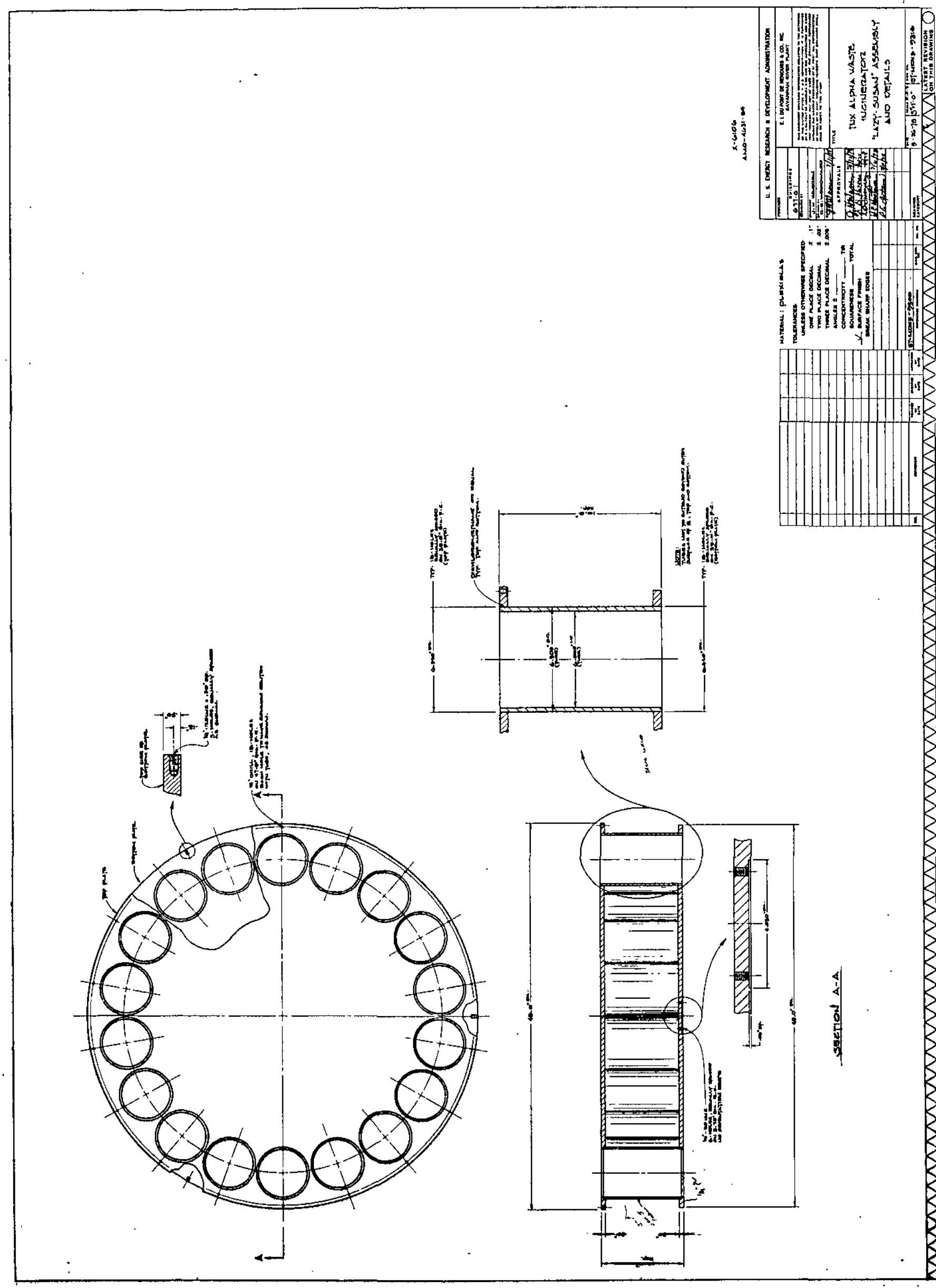

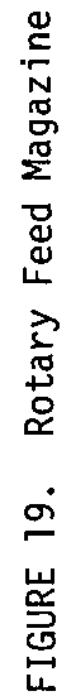


body is made of 304 stainless steel pipe chambers and contains two 316 stainless steel air-actuated knife gate valves.

The rotary feed magazine is made from aluminum for lightness. Rotation from one package position to the next is accomplished in about $3.3 \mathrm{sec}$ by a one-rpm gearmotor (Figure 19c) and controlled by a photoelectric sensor. The aluminum assembly is supported by a thrust bearing in the center and three cam followers on the outside edge of the bottom aluminum plate. Details of brackets and parts for the loading assembly are shown in Figure 20. The entire loading assembly is designed to accommodate cylindrical paper containers up to $5.5 \mathrm{in}$. diameter by 9 in. tall. The pipe sections above each knife valve have photoelectric sensors to detect the location of the package. Due to the location of these sensors and to prevent the package from turning on its side, the packages should be at 1 east 6 in. tall for proper package sensing.

The connection between the metal loading assembly and the silicon carbide primary chamber is made by a weldment (Figures 2 and 4). Fiberfrax rope is wrapped around the tube for the major seal, and Fiberfrax blanket is cut and packed into the steel shell around the ceramic tube as a backup sea1. The blanket is held in place by a cover flange (Figure 4). The weldment is made as a separate unit from the steel shell and loading assembly and is designed for a 66-in.-long primary chamber. The 64-in.-long alumina tubes used in the afterburner may also be used for the primary chamber by lengthening only the connection weldment (Figure 4e) 2 in. An expansion allowance of 0.75 in. is provided between the steel shell and the primary chamber tube.

Temperatures in the loading assembly are expected to vary from $20^{\circ} \mathrm{C}$ at the plexiglass to $500^{\circ} \mathrm{C}$ at the weldment. Air, nitrogen, and steam may be inserted into the loading assembly. A pressure tap is also provided in order to monitor the primary chamber vacuum. If the vacuum is lost, the corrosive pyrolysis gases may be present in the loading assembly; however, the purge gas normally is the only gas present.

The normal operating sequence for the loading assembly is assumed to begin with a package in the chamber between the top and bottom valve. When the automatic sequence is started, the bottom valve opens and the package falls into the horizontal pipe at the bottom of the loading assembly. The bottom valve then closes. At this time, the ram pushes the package into the preset short or long ram stroke. The short stroke positions the package in the center of the primary chamber, and the long stroke drives the ram all the way through the primary chamber. For normal operation, the short stroke is used. At approximately the same time that the ram starts its travel, the rotary feed mechanism advances one position and drops a package onto the top valve. 


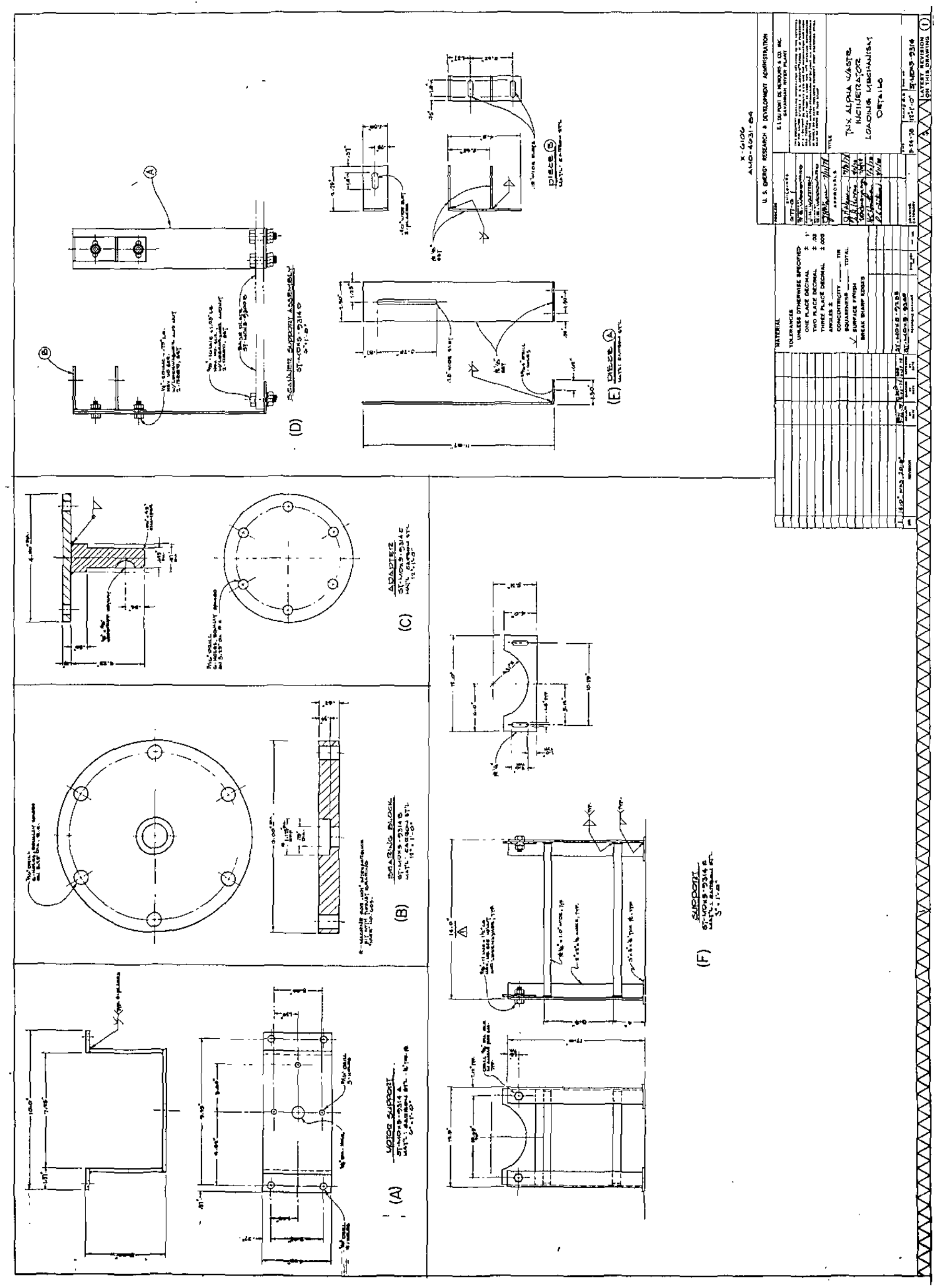


With the bottom valve closed, the top valve then opens, and the package drops onto the bottom valve. The next sequence is then ready to begin. The sequence time can be varied from $90 \mathrm{sec}$ to $999 \mathrm{~min}$. A sequence time of $3.3 \mathrm{~min}$ delivers the design basis eighteen packages per hr.

Operation of the above sequence can be varied manually. Each knife valve can be opened independently for purposes such as dropping the first package on the bottom valve prior to the first cycle. Should a package become jammed at the bottom valve, it is possible to open both valves simultaneously. Safety procedures for operator safety are used to prevent insertion of an operator's arm into the valve chambers; operation of the incinerator is stopped with both valves open since a direct path between the operator and primary chamber is then present. A sequence start switch starts the loading assembly operation which continues through one complete cycle. A manual switch also stops the cycle at a point in the sequence with the only exception being that if the ram is ever energized, it will return to its rest position before stopping.

\section{Ram and Ram Feed Mechanism}

The primary chamber is designed to operate at 600 to $800^{\circ} \mathrm{C}$. The ram, when in its rest position will be approximately at room temperature; however, when it is inserted into the primary chamber, it may be exposed to $800^{\circ} \mathrm{C}$. Normal exposure to the $800^{\circ} \mathrm{C}$ will be less than five sec; however, if the automatic drive system is overridden, the ram may be left in this heat for several minutes or more. Because of this temperature and the corrosive gases and ash, the ram is made of Inconel 601 and Inconel 625.

Normal operation of the incinerator results in an approximately steady state pyrolysis gas evolution and a buildup of waste and ash in the primary chamber. In most cases, the gas flows directly toward the afterburner because of the negative pressure created by the off-gas system. During operation of the incinerator, it may also be desirable to create a path above the waste for the gas to flow to the afterburner. The ram is semicircular and can be rotated until the solid semicircle ram face occupies the top half of the cylindrical chamber. Insertion of the ram clears a path above the waste packages for the passage of gas. The 4in.-1ong prow on top of the ram (Figure 2la) sticks out in front for stirring the waste and ash to promote better pyrolysis. The 0.375-in.-thick prow and end plates are made from Inconel 601 . The 0.125-in.-thick semicircle is made from Inconel 625 rolled plate. Both of these materials should be equally acceptable, and the two different materials should provide a good test if differences in their performances occur. The ram handle, a 304L stainless 


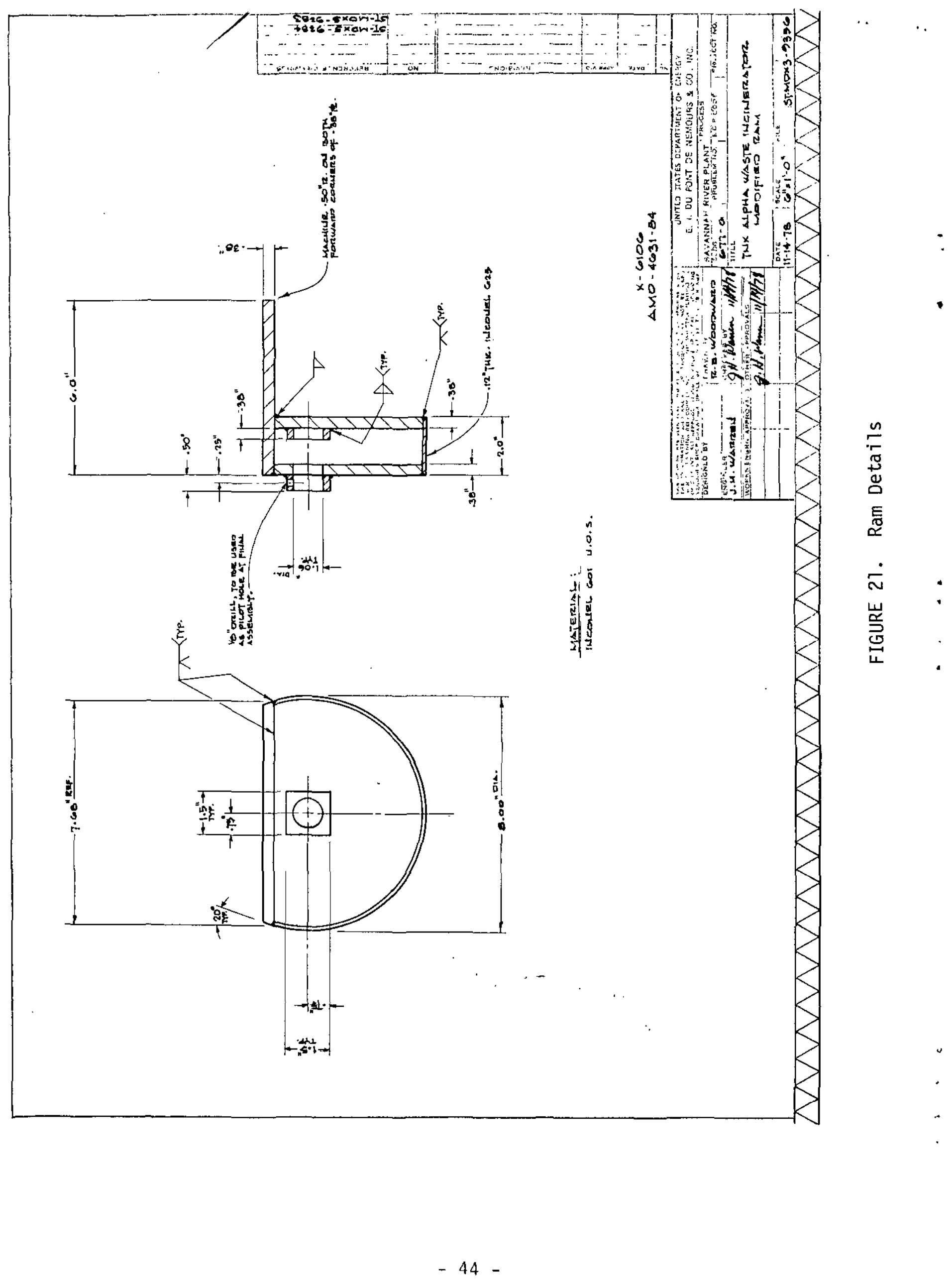


steel, 3/4-in. Sch 40 pipe (Figure 22), is inserted into the ram for stability. The handle is fastened by a pin at the rear of the ram. Stainless steel is used for the rod because of the normal low exposure time in the high temperature environment and the ease of replacement of the rod.

If the ram is inserted over the waste and ash in its upside down position, rotated to its normal position, and pulled back, the entire waste and ash pile will be dragged to the rest position. As a result of this procedure and during normal operation, some ash will collect behind the ram; therefore, an 8-in.-diameter ash drop covered with a blind flange is installed at the base of the loading assembly (Figure 18). If the waste and ash are pulled back, removal of the blind flange readily provides access to and removal of the material. The operator uses safety precaution during this operation because the ash can be $\sim 800^{\circ} \mathrm{C}$, and there is a direct path to the primary chamber.

The 304L stainless steel ram rod rides in two oversized Graphitar (Figures 2 and 23 ) bushings that are press-fitted in two blind flanges approximately six inches apart. The oversize allows for expansion of the $304 \mathrm{~L}$ stainless steel rod when it is exposed to $800^{\circ} \mathrm{C}$. Sealing is provided by a Fiberfrax blanket packing inserted in the 6-in.-long pipes between the two flanges of the seal chamber.

Rotation of the ram in the primary chamber is produced by a Boston gearmotor attached to and trailing the ram handle. The ram is inserted into the primary chamber by a gearmotor and pulley drive (Figure 21). The linear position of the ram is determined by microswitches on the top of the support table (Figure 21) and actuated by the bottom of the gearmotor dolly. Two microswitches are provided at each end of the table, one for normal operation and the other for safety if the first switch malfunctions. Normal operation provides for two ram stopping positions in the primary chamber. The short stroke determined by the center microswitch puts the waste package in the center of the primary chamber. Slots in the top of the table have been provided to vary this position by approximately one foot. The controls are designed so that this switch can be overridden if the long stroke is desired for ash cleanout or for providing a slot for gas travel at the top of the waste as discussed in the preceding section.

Ram rotation is performed by a push bottom switch. A rotary feed mechanism switch advances the rotary feed one position. Emergency ram forward and reverse switches can be used to drive the ram directly, bypassing a11 normal operating controls. If pyrolysis of an undesirable waste feed occurs with an excessive temperature rise, the emergency forward switch can be used to drive the ram in, pushing the material into the ash-out subassembly and, therefore, slowing down or stopping the pyrolysis. 

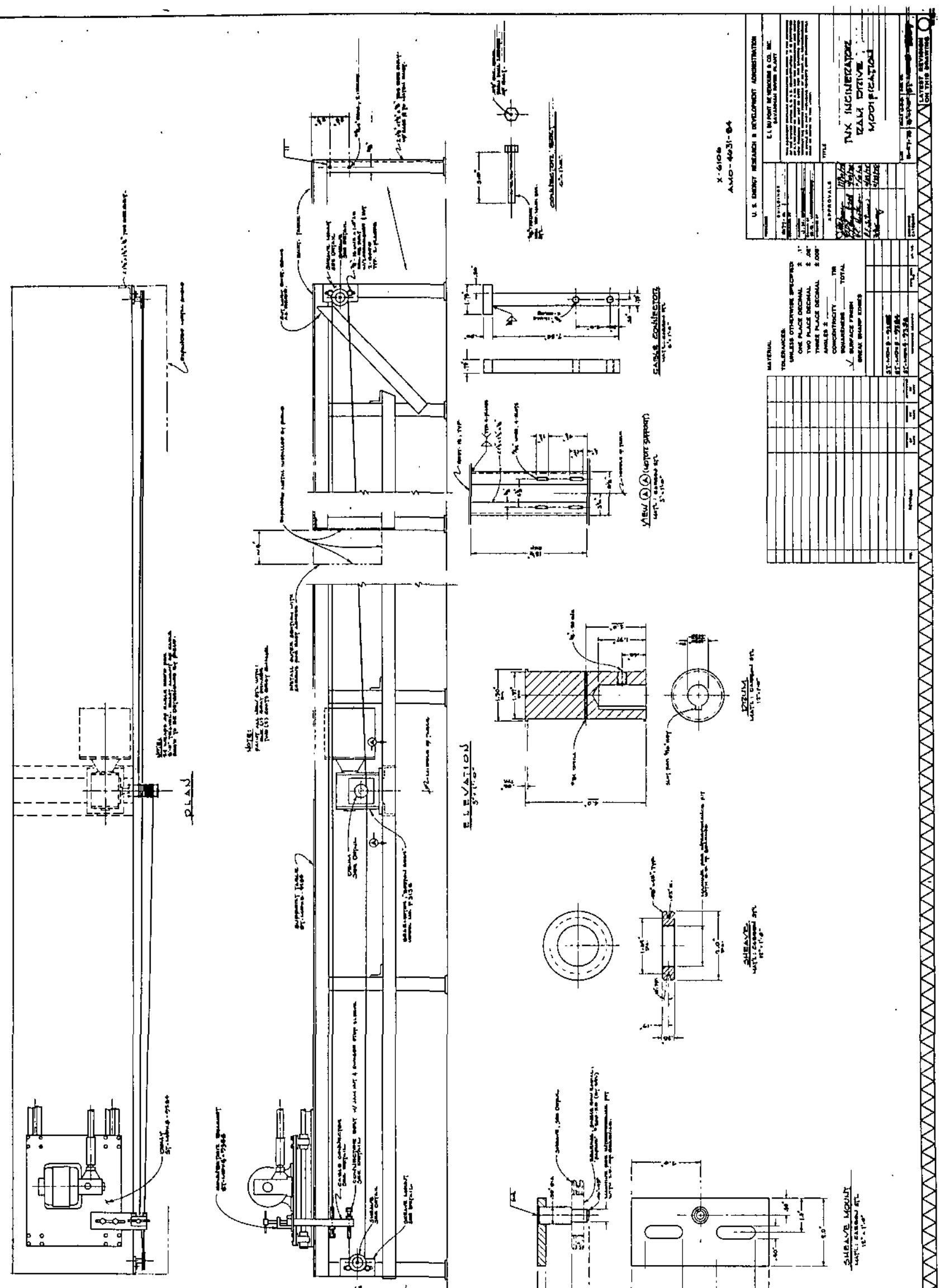

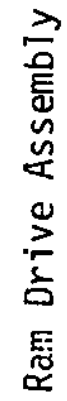
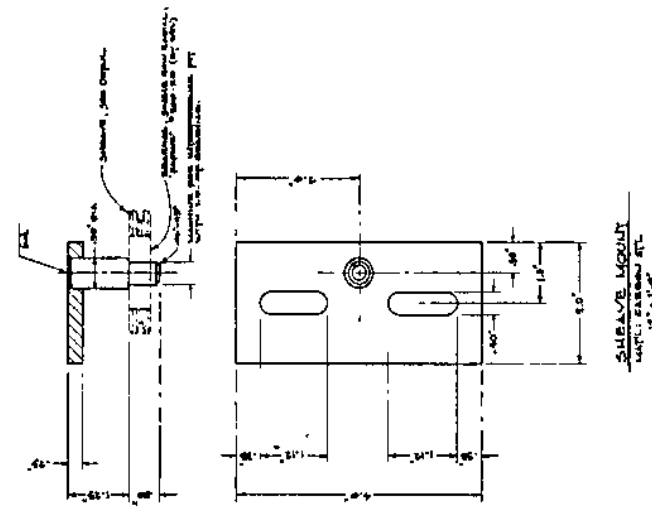


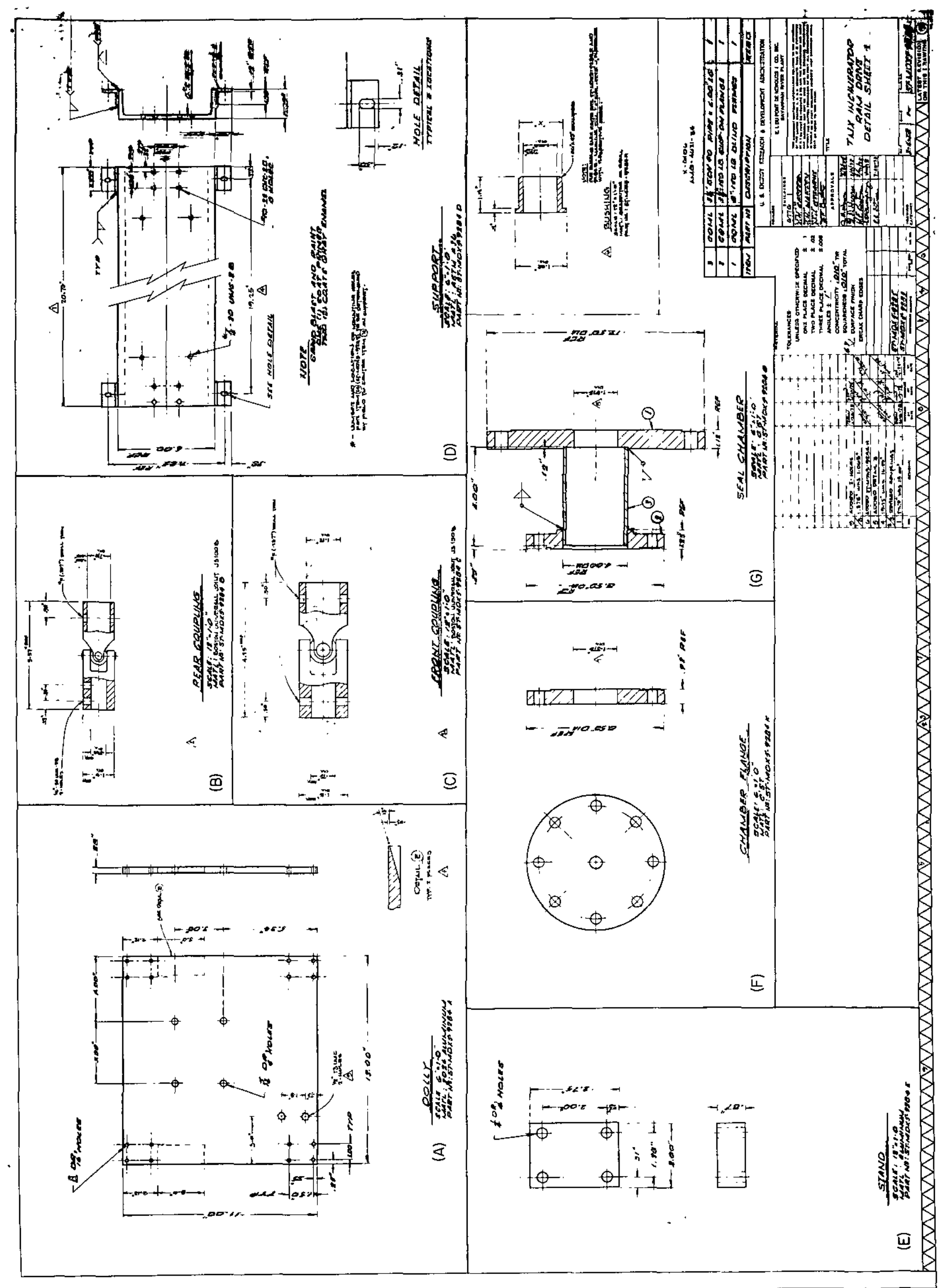




\section{Incinerator Operation}

Combustion is regulated by controlling the air flow to the two combustion chambers and the waste feed to the primary chamber. Air flow to the primary relative to secondary combustion chamber should be in the range of 5 to $30 \%$ of total feed air. Combustion feed to the secondary chamber can be preheated to $500^{\circ} \mathrm{C}$.

Two modes of incinerator operation have been proposed: static and dynamic. The static mode involves setting the combustion air at a fixed upper limit and feeding waste at a rate which does not exceed stoichiometric air demand as indicated by the oxygen analyzer in the secondary chamber (Figures 24 and 10).

The dynamic mode is to set the air flow to the incinerator at a nominal rate and allow the oxygen analyzer to regulate the air flow if the oxygen depletion in the secondary chamber falls below a certain setpoint (i.e., stoichiometric demand).

In both modes of operation, the pressure in the incinerator is kept well below atmospheric by a vacuum regulator which operates a valve between the venturi quencher and the fiber bed scrubber.

Various tests of any combinations of feeds may be performed to determine the best options for controlling the operation of the incinerator under normal and upset conditions. There is provision for air, steam, and nitrogen to the primary chamber: only nitrogen and air are fed to the secondary chamber. Air is used under normal conditions of operation. Steam may be used to reduce the temperature of the gas and for emergency quenching in the primary. Steam has also been mentioned as a possible aid for polymer decomposition. Nitrogen is used to purge the incinerator in upset conditions but does not quench the pyrolysis of the waste in the primary combustion chamber.

\section{Off-Gas Treatment}

The off-gas treatment system is designed to remove suspended particulates and to neutralize the exhaust gas before venting to atmosphere. The hot gas exiting the incinerator at $1000^{\circ} \mathrm{C}$ is spray-cooled to $50^{\circ} \mathrm{C}$ in a venturi quencher with recirculating water. Hydrogen chloride gas from polyvinyl chloride waste components will be gradually absorbed by the quench water until the HC1 concentration reaches about $20 \%$ under equilibrium conditions. The scrubbing acid is cooled to maintain temperature, filtered to remove suspended matter, and then recirculated. 


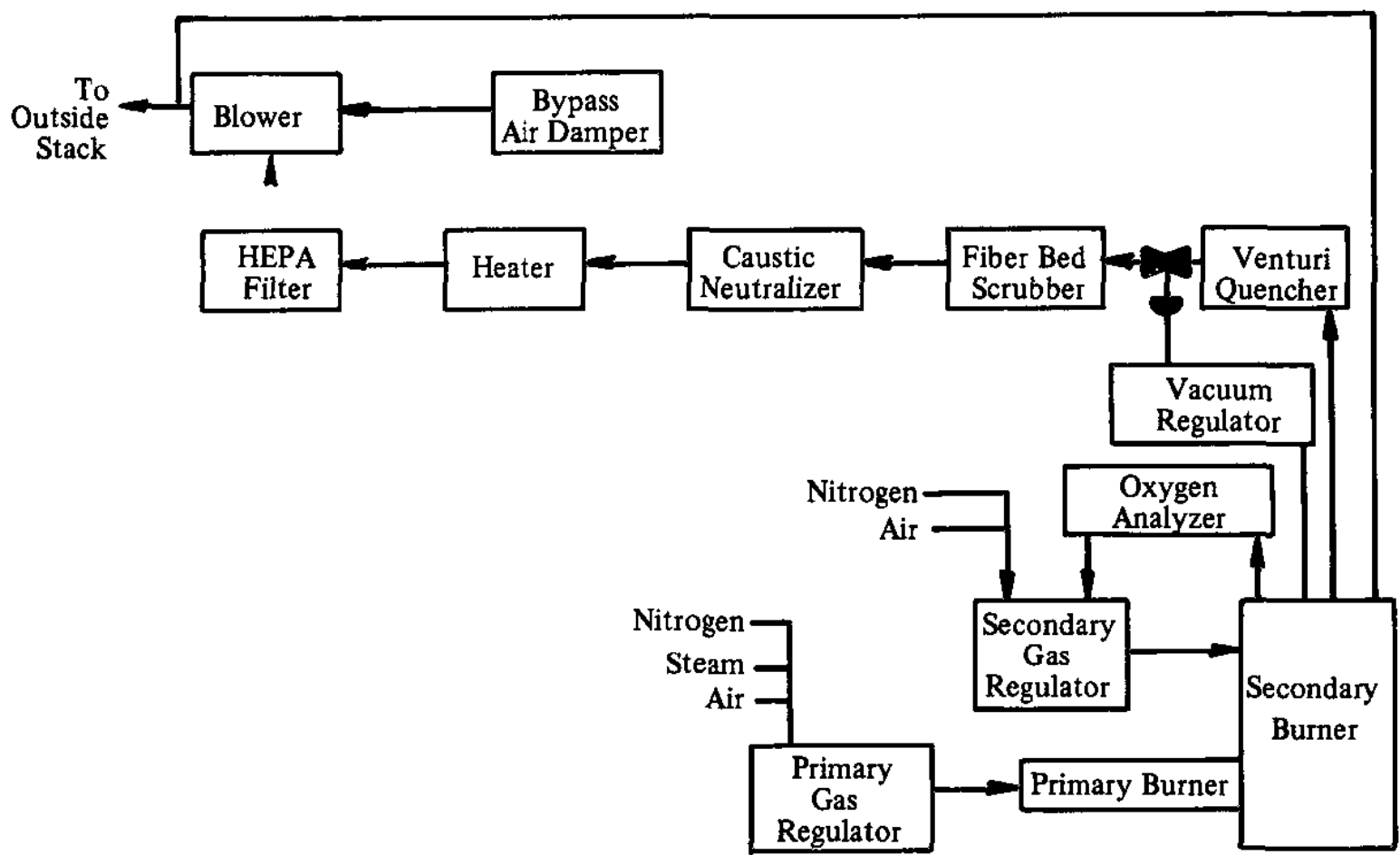

FIGURE 24. Incinerator Flow Diagram

Fine particulates are then removed from the gas phase with high pressure water sprays to impinge suspended matter against a fibrous web which is continuously washed to keep the solids in the liquid phase. Again, the scrubbing water turns to hydrochloric acid, and the fines are removed from the acid by filtration.

Next, the clean but acidic gas is neutralized in a caustic scrubber, filtered through HEPA filters and discharged to atmosphere. A condenser and a reheater are included in the gas stream to ensure dry HEPA filtration. Sodium chloride solution from the neutralizer will be discharged to the G-Area seepage basin; in a waste operation, the salt will be evaporated to dryness for onsite burial.

\section{Venturi Quencher}

The venturi quencher is designed to cool the hot off-gas from 1000 to $50^{\circ} \mathrm{C}$ and to remove coarse suspended matter. The jet venturi is made of Inconel 625 for acid resistance, and the separating tank is made from Heteron 197 flame retardant polyester resin. A 20 -gpm spray at $40 \mathrm{psi}$ and $40^{\circ} \mathrm{C}$ will provide the necessary gas cooling with a 15-ton chiller to remove the sensible heat. An alternate emergency spray is provided to quench the gases by latent heat of evaporation of process water. The recirculating acid will be filtered continuously to remove suspended matter. 
Fibrous Bed Scrubber

This unit is designed to scrub out fine suspended particulates, by impingement, with high velocity water spray. A 300-psi atomizing spray penetrates the incoming gas, impinging entrained particulates against a rigid porous fiber bed. The bed is continuously washed with another low pressure spray. Again, the recirculating water will turn to hydrochloric acid as the $\mathrm{HCl}$ from PVC is absorbed. Filters are provided to clean the recirculating acid.

Neutralizing Scrubber

A standard packed column design is used to neutralize the acidic off-gas with sodium carbonate (or sodium hydroxide). A mist eliminator is incorporated in the column design, and a solution makeup tank is provided.

\section{Gas Discharge}

The clean neutralized gas is reheated (to prevent condensation) and passed through a HEPA filter. Exhaust is provided with a turbocompressor, maintaining a 60-in. water vacuum at the design gas flow of $100 \mathrm{cfm}$.

\section{CONCLUSION}

This report describes the design of an electrically heated two-stage alpha waste incinerator. The incinerator has been built. Operation was begun in March 1979.

\section{ACKNOWLEDGMENTS}

The author would like to thank H. E. Hootman for his valuable discussions during the design of the incinerator. Appreciation is given to $\mathrm{T}$. J. Pazik for the air mixing tests and to $\mathrm{L}$. O. Dworyjanyn for his information on the off-gas treatment system. Thanks is also given to R. E. Woodward for his many hours of drafting time. 


\section{REFERENCES}

1. H. A. Taylor, R. H. Allardice, J. G. Boyle, L. P. O'Conner, and M. J. S. Smith. "UK Experience in the Management of Pu Contaminated Solid Waste," in Proceedings of the Seminar on the Management of Plutonium-Contaminated Solid Wastes, Marcoule, France, October 14-16, 1974. Conf. 741026 (1974).

2. B. L. Perkins. Incineration Facilities for Treatment of Radioactive Wastes: A Review. ERDA Report LA-6252, Los Alamos Scientific Laboratory of the University of California, Los Alamos, NM (1976).

3. A, H. Shapiro. The Dynamics and Thermodynomics of Compressible Fluid Flow. Vol. 1, The Ronald Press Co., New York, NY (1953) p 47. 